\title{
Inflammatory cardiomyopathy: A review and meta-analysis of pathophysiology, diagnosis and clinical management
}

\author{
Aref Albakri* \\ St-Marien hospital Bonn Venusberg, department of internal medicine, Bonn, Germany
}

\begin{abstract}
Inflammatory cardiomyopathy (ICM) is a serious long-term sequelae of myocarditis (MC), defined as the inflammation of the heart muscle accompanied by cardiac dysfunction. Definitive diagnosis of ICM remains a challenge due to the lack of pathognomonic clinical signs and symptoms, as well as the disease mimics a variety of other non-inflammatory myocardial diseases. The disease has multiple aetiologies including infectious, autoimmune, drugs and toxins. Diagnosis relies on histological, immunological, immunohistochemical and molecular findings of infectious causes and the evidence of cardiac dysfunction. Whereas endomyocardial biopsy is the diagnostic gold standard for $\mathrm{MC}$ and ICM as well as distinguishes aetiological forms, its use in routine clinical setting is infrequent. The result is the lack of certainty in the epidemiological impact and the natural history of ICM. Moreover, ICM may resolve spontaneously, recur or become chronic leading to death or the need for cardiac transplantation. Traditional diagnosis based on the Dallas Criteria considered MC a relatively rare cause of ICM, HF and sudden cardiac death. However, the recent use of highly sensitive immunohistochemical and molecular tools applied to EMB together with advances in non-invasive imaging modalities suggest the prevalence of the MC and ICM could be much higher than previously estimated. Therefore, the present study reviews published literature on the epidemiology, aetiology, pathophysiology, diagnosis and clinical management to broaden understanding of this potentially treatable but life-threatening disease entity.
\end{abstract}

\section{Introduction}

Inflammatory cardiomyopathy (ICM) is a cardiac condition characterized by the inflammation of the muscular tissues of the heart (the myocardium) accompanied by alterations in myocardial morphology and function. Clinically, ICM exhibits typical morphological characteristics of idiopathic dilated cardiomyopathy (iDCM) [1], and it is the leading cause of non-ischemic heart failure (HF), accounting for nearly one quarter (25\%) of HF patients in the United States and Europe [2]. Its known aetiologies are alcohol, infections, drugs, toxins, and metabolic abnormalities, which may lead to myocardial injury and to a common pathway of cardiac dilatation and HF. Recent clinical evidence also points towards a genetic basis of iDCM, suggesting that in a sub-group of ICM patients, familial transmission is a potential aetiology. Although conventional HF regimens such as diuretics, angiotensin-converting enzyme-inhibitors (ACE-inhibitors), digitalis, beta-blockers, vasodilators, and aldosterone antagonists have proved both safe and efficacious in the treatment of iDCM, accumulating clinical evidence suggests these HF regimens may be less effective for ICM patients [2]. Thus, the emerging question is whether medical treatment that reduces or eliminates inflammation would produce additional clinical benefits among ICM patients compared with the exclusive use of the standard HF regimens.

The answer to the question remains controversial for several reasons, and thus the need for a better clinical understanding of ICM as an important sub-type of DCM. First, the clinical presentation of ICM exhibits a wide heterogeneity. Whereas most patients diagnosed with myocardial inflammation are asymptomatic with spontaneous resolution, a few others present with a fulminant course characterized by severe HF, cardiogenic shock and a high mortality rate [3]. A few other patients with a less acute form of ICM usually present with moderate myocardial dysfunction and HF, and they account for the largest group in most clinical trials [4]. Second, a confirmatory diagnosis of ICM is very general. The standard Dallas criteria requires both inflammatory cells and myocyte necrosis, and has a great variability of about $40 \%$ among expert pathologists [5]. Third, it is unclear at what time the initiation of anti-inflammatory therapy (acute, subacute or chronic phase) would produce the most effective clinical outcomes during the course of the disease. Given these challenges, this paper synthesizes published evidence about ICM with a focus on aetiology, pathophysiology, diagnosis and clinical management.

\section{Definition}

Studies on inflammation of the heart muscles frequently associate ICM with myocarditis (MC). Earlier expert consensus guidelines on the classification of cardiomyopathies (CM) by both the European Society of Cardiology (ESC) [6] and the American Heart Association (AHA) [7] categorized ICM under MC cardiomyopathy and as a sub-category of acquired DCM. The association between MCs and ICM is attributable to the lack of a clear consensus on the meaning of the terms MC and ICM, where some authors speak of ICM in the phase of acute cardiac inflammation. However, MC and ICM are separate clinical entities. In a more recent guideline on diagnostic and treatment strategies for specific DCMs, the AHA recognizes ICM as distinct clinical entity from $\mathrm{MC}$, in which case, MC is the leading cause of ICM [8].

Clinically, the term MC describes an inflammation of the myocardium secondary to infections, the exposure to toxic substances

${ }^{\star}$ Correspondence to: Aref Albakri, St-Marien hospital Bonn Venusberg, department of internal medicine, Bonn, Germany, E-mail: arefalbakri@yahoo.com

Key words: inflammatory cardiomyopathy [icm], inflammatory dilated cardiomyopathy [idcm], myocarditis [ $\mathrm{mc}]$

Received: May 10, 2020; Accepted: May 18, 2020; Published: May 25, 2020 
or to autoimmune processes. During the initial acute phase of infection, a specific trigger can induce an autoimmune response ranging from transient, to mild and to fulminant. If the infection persists, chronic infection may develop in the presence or absence of inflammation. In some patients, inflammation may persist even after the successful elimination of the causative infectious agent [9]. On the other hand, ICM is a progressive cardiac condition characterised by alterations in the function and morphology of the myocardium with histological, immunological and/or immunohistochemical evidence of both inflammation and myocardial tissue remodelling. Histologically, ICM developed in the presence of inflammatory infiltrates in the myocardium accompanied by cardiomyocyte degeneration and necrosis of non-ischemic cause [10]. Thus, ICM is MC in the presence of cardiac dysfunction.

Although MC is the leading cause of ICM, it is difficult to assess the absolute risk of developing ICM secondary to MC due to the lack of a non-invasive gold standard for early and sensitive diagnosis $[9,10]$. Moreover, the use of the diagnostic gold standard, endomyocardial biopsy (EMB) in clinical settings is infrequent. Since ICM shares morphological characteristics with idiopathic dilated cardiomyopathy (iDCM), some guidelines refer to ICM as inflammatory DCM. With increased clinical understanding of ICM, it is now evident that pathological injury in ICM patients occurs at the cellular level. Thus, an accurate diagnosis requires tissue analysis with EMB [10]. Histological findings have important prognostic implications and in some cases may guide additional case-specific treatment regimens to the standard symptomatic HF regimens [11,12].

\section{Epidemiology}

The prevalence of ICM has been difficult to determine due to a wide heterogeneity of pathologies contributing to its development, and significant regional and geographic variability of these pathologies. Most available epidemiologic studies report the prevalence of DCM or nonischemic CM without a specific focus on ICM. However, because of the close association between MC and ICM, most epidemiological studies refer to the prevalence of MC to approximate that of ICM. However, as already indicated, it is difficult to assess the absolute risk of developing ICM after MCs, and as such, a significant number of subclinical cases of MC usually go undiagnosed, which leads to under estimation of the absolute risk for the development of ICM. Some prospective studies adopting a clinical-epidemiologic design evaluating the progression of MC diagnosed by EMB report a consistent progression into DCM of about 30\% [13-16]. Post MC, ICM portends a poorer prognosis, and patients in American Heart Association (AHA) functional classes IIIIV, only cardiac transplantation produces a definitive resolution [13].

The true incidence of MC has also been difficult to ascertain due to the complex definitive diagnosis in routine clinical practice. Moreover, since cardiac biopsy and viral genomes analysis are infrequent in many regions of the world, the prevalence of viral myocarditis in many regions of Africa, Asia, the Middle East and South America remains unknown. Nevertheless, recent estimates suggest that in young adults who have succumbed to sudden cardiac death, post-mortem analysis reveal that between $2 \%$ and $42 \%$ have clinical evidence of MC, with some studies reporting up to $46 \%$ incidence of MC in children with idiopathic DCM [10]. Previous studies based on the Dallas diagnostic criteria report an incidence of biopsy-proven MC in between $5 \%$ and $16 \%$ of DCM cases [17]. More recent studies report that about a half (50\%) of patients with a clinical diagnosis of DCM exhibit immunohistochemically detectable MC, classified as ICM $[18,19]$. Based on the reported incidence rates,
ICM is the leading aetiology of DCM [20]. Although some viruses may be present in normal hearts, their significant remains to be elucidated. Some studies associate the presence of virus in the myocardium with negative prognostic implications [11,21] while others have not demonstrated any effect of viral presence in the myocardium in the prognostication and the evolution of the LV function $[19,22]$.

\section{Aetiology}

ICM in the presence of chronic HF is the most severe long-term sequela of $\mathrm{MC}$ associated with dilation of the cardiac chambers leading to systolic dysfunction [22-26]. Most guidelines recognize MC as the major cause of ICM, and thus, aetiologies of ICM have been associated with those of MC. Although the aetiology of MC often remains undetermined, a large variety of infectious agents, predominantly viral, systemic diseases, and prolonged exposure to environmental toxins are potential causes of the disease (Figure 1).

\section{Infectious aetiologies}

Inflammation of the muscular tissues of the heart can result from a wide spectrum of infectious pathogens including viruses, bacteria, fungi, protozoa, and parasites. Viral and post-viral MC remains the most common aetiological cause of both acute and chronic ICM. Several different cardiotropic viruses cause more than a half $(50 \%)$ of cases of paediatric ICM $[27,28]$. The other half may result from environmental factors such as toxins, alcohol, cytotoxic chemotherapy, metabolic aberrations or immunologic mechanisms. These later aetiologies may characterize autoimmune $\mathrm{MC}$ from the onset or may be the consequence of viral MC itself [29]. A larger proportion of the evidence for infectious agents as the cause of ICM were reported before the year 2000 with more recent studies interested with therapeutic interventions.

\section{Viral aetiologies}

The bulk of earlier studies implicated coxsackie viruses as the most frequent cardiotropic viral agents causing ICM [30,31]. Coxsackievirus is a member of the enterovirus genus of viruses within the picornaviridae family. They are positive-sense single-stranded RNA viruses divided into coxsackievirus group $\mathrm{A}(\mathrm{CVA})$ and group $\mathrm{B}(\mathrm{CVB})$ species. A report by the World Health Organization (WHO) covering 10 years between 1975 and 1985 implicates CVB as the most frequent inflammatory agents in cardiovascular diseases (CVD) accounting for 34.6 per 1,000 cases. The other frequent inflammatory agents were influenza B virus accounting for 17.4 per 1,000 cases, influenza A, 11.7 per 1,000 cases, CVA, 9.1 per 1,000 cases and cytomegalovirus (CMV), 8.0 per 1,000 cases [32]. Moreover, several clinical studies have confirmed the prevalence of enterovirus as causative agents for the inflammation of the heart muscle [30-33], some revealing significantly higher serological titres compared to controls [34-36]. On the other hand, the use of the traditional enteroviral diagnostic methods found Coxsackie virus infection in only $2 \%$ of consecutive studied MC in a 5-year study in a Finnish military hospital [37].

Clinical tests based on molecular techniques report the frequency of myocardial enteroviral infections in between $30 \%$ and $50 \%$ of DCM cases diagnosed with infectious aetiology $[27,28,38,39]$. Although data on respiratory tract viruses such as adenovirus, Epstein-Barr virus (EBV), and influenza virus is limited, these viruses can cause $\mathrm{MC}$ at variable frequencies $[31,32,37,40]$. In particular, adenovirus have been reported as an important causative infectious agent of MC and DCM in both paediatric and adult populations $[27,28,41]$. Reports of rhinovirus- 


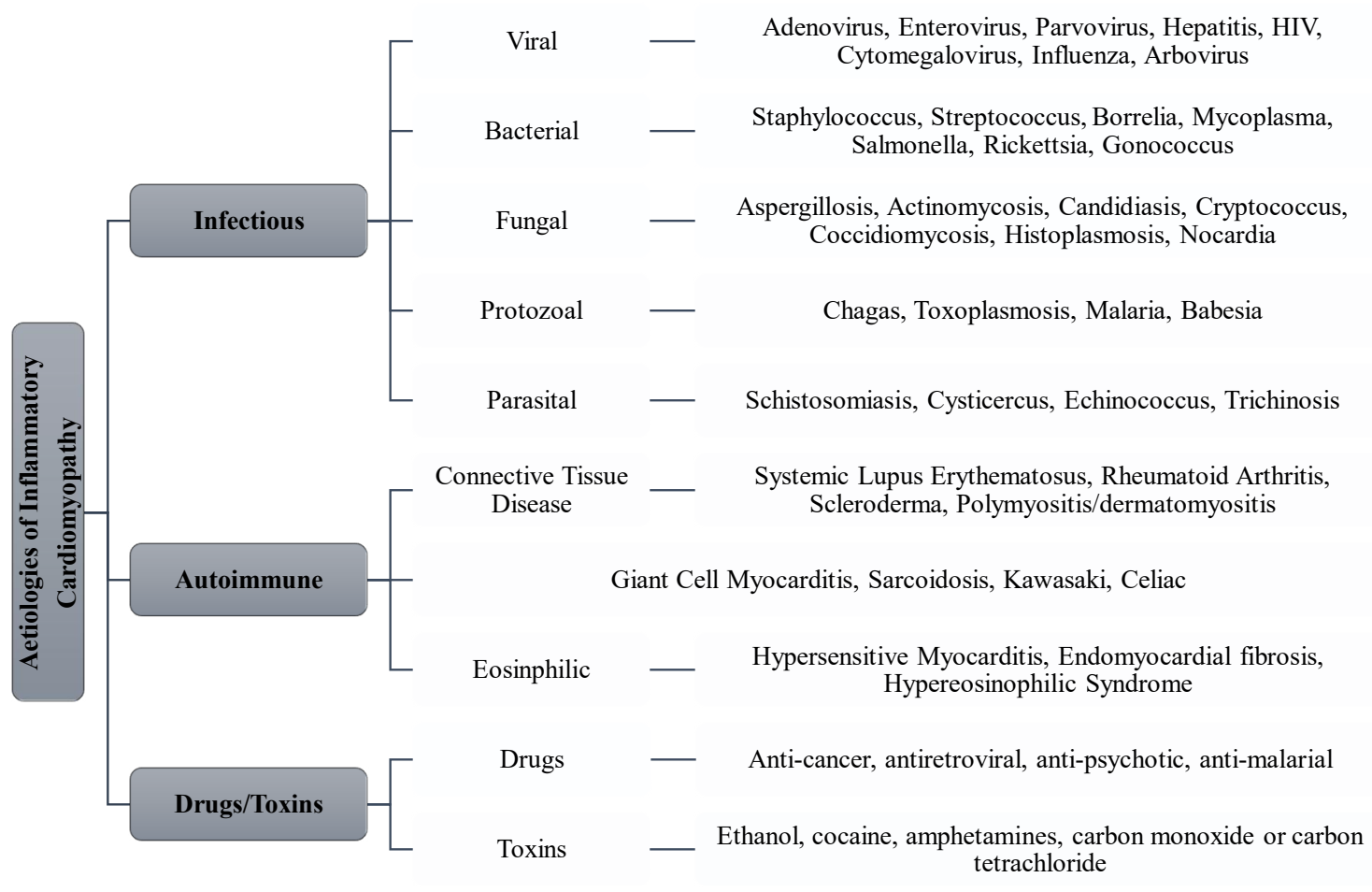

Figure 1. Major aetiologies of inflammatory cardiomyopathies

associated myocarditis are rare in literature although the U.S. Centre for Disease Control has registered several cases [32,42].

Cytomegalovirus infection is an uncommon cause of acute MC/ ICM in previously healthy people but recognized as a cause of acute infectious MC in the herpes group of viruses [43]. Moreover, some studies report CMV-specific genome in the cardiomyocytes of EMBs in up to $15 \%$ of patients with acute myopericarditis [44]. Thus, CMV might be a more frequent cause of $\mathrm{MC}$ that previously reported. Furthermore. CMV infection is a peculiar viral disease in transplant recipient patients particularly those with multi-organ involvement because specific cytopathic features are only exceptionally observed [43-45].

Earlier studies also implicated the mumps virus as a causative agent for infectious ICM. During or after mumps diagnosis, mild or subclinical myocardial infection maybe present with about $15 \%$ of the cases exhibiting changes in ST-T wave. Mumps associated MCY maybe the initial step in the pathogenesis of endocardial fibroelastosis $[28,46]$. However, the incidence of mumps-associated MC, previously considered a major cause of infant mortality, has declined remarkably over the recent decades because of the introduction of mumps vaccine.

Parvovirus B19 (PVB19), which causes the disease erythema infectiosum, is a rare but a severe cause of infectious MC in infants and children [47-49]. The virus is also responsible for hydrops fetalis and foetal death [50,51]. The presence of B19 receptor (erythrocyte $\mathrm{P}$ antigen) in foetal myocardial myocytes suggests the involvement of intrauterine MC in the pathogenesis of foetal hydrops following PVB19 infection [47,51]. The demonstration of the involvement of hepatitis $\mathrm{C}$ virus (HCV) in MC and DCM patients has been recent [52,53].

Infectious MC and ICM is a common complication in patients infected with human immunodeficiency virus (HIV) or diagnosed with patients with its sequela - Acquired Immuno-Deficiency Syndrome (AIDS). Infectious MC affects about $45 \%$ to $52 \%$ HIV/AIDS patients
[54]. However, cardiac manifestation in HIV/AIDs is not solely due to the viral infection. It can have various other form of pathogenesis. The cases of MC and ICM in HIV/AIDS patients is variable and may be difficult to establish, especially among patients with multiple opportunistic infections. The presence of other viruses in HIV/AIDS patients such as Coxsackie virus and Toxoplasma gondii may also cause myocardial inflammation [55].

Most of the evidence for viral associated ICM comes from earlier studies published before 2000. However, a few studies post-2000 suggest a shift in the viral spectrum. The shift is from the previous domination of adenovirus and enterovirus to the current parvovirus B19 (PVB19) and human herpes virus 6 (HHV-6) [56]. Data from the Marburg Registry confirms the current prevalence of PVB19 and HHV6 in patients suspected with MC who underwent EMB [57]. Although, there are no recent studies in the past decade in non-transplanted CM patients, the prevalence of specific viruses maybe similar between transplanted and non-transplanted CM patients [56,58].

\section{Non-viral aetiologies}

Nowadays, non-viral aetiologies of infectious ICM are rare although the can cause significant morbidity and mortality. However, non-viral causes are common in immunosuppressed patients with secondary involvement of the myocardium. In diphtheric patients, MC is the leading cause of death through the action of exotoxin secreted by the bacterium Corynebacterium diphtheriae. Diphtheria still causes morbidity and mortality in low-income countries [59] but rare in Western countries because of vaccination although a resurge appeared in Scandinavian countries in the mid-1980s particularly among alcoholics [60].

Beta-haemolytic streptococci is a causative agent of nonrheumatic MC often due to bacterial exotoxins [61]. Rheumatic MC 
involving valvular and perimyocardium is a major cause of paediatric hospitalizations and cardiac deaths globally, with disproportional incidence in developing countries. Autoimmune response to Group A streptococcal antigens during pharyngitis leading to cross-reaction of antibodies and immunocompetent cells with antigens in the myocardium is believed to be the primary pathogenic mechanisms in rheumatic MC. The discovery of enteroviral RNA replication and protein synthesis in valvular tissues in patients with chronic rheumatic heart disease supports viral aetiology or cofactor in some patients [62]. Bacterial endotoxin may also contribute to the pathogenic mechanisms in meningococcal MC. Myocarditis has been reported in about three quarters $(78 \%)$ of patients with meningococcal septicaemia in the presence of acute endotoxinaemia [63].

Myocarditis is a rare complication of Salmonella septicaemia caused by Salmonella typhi or paratyphi. Yersiniosis is an infectious disease caused by bacterium of the genus Yersinia in which myocarditis may be a mild complication whose pathogenesis may involve the immune system [64]. Myocarditis affects between $1 \%$ and $8 \%$ of cases of Borrelia burgdorrferi infection and the involvement of the specialized myocardium may result in atrioventricular block [65]. Patients with infected with Mycoplasma pneumonia may develop mild MC and a third will exhibit abnormal ECG findings [66].

Infection by the bacterium Chlamydia psittaci is rare in humans and can cause psittacosis. Subclinical or mild MC is a complication in $5 \%$ to $15 \%$ of patients infected with Chlamydia psittaci with marked cardiac insufficiency $[67,68]$. Cases of MC in patients infected with the bacterium Chlamydia trachomatis are rare although a few published cases report fatal especially in paediatric populations [67]. A mild form of MC may accompany infection by Chlamydia pneumoniae but a case of sudden cardiac death in a young athlete has appeared in literature [69].

Cardiac involvement is a common complication in patients infected with rickettsial infection in the presence of prominent vasculitis because the bacterium rickettsiae has a special tropism for endothelial cells. Infection with Coxiella burnetii causes Q fever. Myocarditis is a rare complications but endocarditis is more common [70]. Chagas' disease caused by Tripanozoma cruzi infection is a common cause of MC and ICM in both urban and rural areas of South America [71]. African trypanosomes, Tripanozoma gambiense and Tripanozoma rhodesiense, occasionally may lead to MC and ICM [72].

In recipients of cardiac transplants, infection by Toxoplasma gondii may lead to severe cardiac complications. In a study on antibody negative recipients of cardiac transplants, 57\% developed toxoplasma MC [73] but in a related study, only $4 \%$ to $53 \%$ antibody positive transplant cases develop MC although this difference may be the result of the different antibody testing methods in the two studies [74]. However, following the introduction of pyrimethamine prophylaxis, cardiac complications associated with Toxoplasma gondii infection has declined significantly.

Infectious MC due to fungal infection frequently manifests in the setting of disseminated disease. The most frequent fungal causative agents for MC and ICM is Aspergillus fumigatus [75]. However, the incidence of invasive fungal infection and disease has substantially increased over the past few decades associated with an increase in the population of immunocompromised patients. The main risk factors for severe fungal disease are administration of broad-based antibiotics, corticosteroids and cytotoxic agents, invasive medical procedures and HIV/AIDS, where association of fungal and other infective agents is frequent [76]. Post-mortem diagnosis of fungal $\mathrm{MC}$ is challenging because clinical findings of the involvement of the myocardium is usually absent or non-definitive and blood cultures are often negative and other laboratory tests are ineffective.

Parasitic infections are rare causes of MC and ICM. Trichinella is the most common parasite causing infective MC and ICM. It is of the genus of parasitic round worms and its species include T. spiralis, T. pseudospiralis, T. nativa, T. nelsoni, T. bitovi, T. murelli, and T. papuae in which T. spiralis is the most prevalent cause of ICM $[77,78]$. Other helminths can also lead to myocardial infection resulting in inflammation often in the setting of multi-organ involvement [22]. Other fungal diseases that may lead to infective CM and ICM include Trichiniasis, Echinococcosis, Schistosomiasis, Ascariasis, Heterophydiasis, Filariasis, Paragonimiasis, Strongyloidiasis, Cysticercosis, and Visceral larva migrans.

\section{Non-infectious aetiologies}

Infective MC and ICM can also result from autoimmune diseases and prolonged exposure to cytotoxic drugs or environmental toxins. However, cases of non-infectious CM are uncommon relative to infectious (or viral) causes. The pathogenic mechanisms between infectious and non-infectious aetiologies differ but both lead to common pathway of myocardial inflammation, dilatation and dysfunction.

\section{Autoimmune diseases}

Several autoimmune conditions can involve longstanding MC as either a primary or a secondary complication leading to myocardial dilatation and dysfunction. The various autoimmune diseases that can cause ICM include sarcoidosis, Churg-Strauss and eosinophilic MC, giant cell MC (GCM), dermatomyositis, inflammatory bowel disease, systemic lupus erythematosus, rheumatoid arthritis, scleroderma, and chronic lymphocytic MC, Kawasaki, and celiac disease [79]. Autoimmune diseases occur secondary to a defective function of features that contribute to the non-reactivity of the immune system towards self-antigens. Its main characteristic is a high concentration of autoantibodies reacting with autoantigens. [80,81].

Autoantibodies are antibodies (immune proteins) produced by the immune system that target and react with own tissues and organs. The immune system produce autoantibodies when it fails to distinguish between "self and non-self" antigens and these autoantibodies cause many autoimmune diseases. A variety of stimuli including infections, drugs, environmental toxins and prior lesions may induce immune response that produces autoantibodies. On the other hand, autoantigens are normal or complex proteins (sometimes DNA or RNA) recognizable by the immune system of patients suffering from a specific autoimmune disease. Autoantigens can react with the effector arm of a patient's own immune system [82-86]. The immune system can direct autoantibodies to a wide spectrum of autoantigens in the organ that contains the autoimmune lesion.

The development of autoantibodies depend on its activity, accessibility to autoantigen targets and the actions of the immune response effector mechanisms [87]. Some diseases with cardiological effects such as rheumatic fever, post-pericardiotomy syndromes and collagen diseases exhibit immunopathological responses but are not considered autoimmune diseases. In ICM patients, autoantibodies that attack autoantigens are pathogenic agents or a secondary effect of tissue aggression. The presence of autoantibodies in patients with $\mathrm{CM}$ and ICM are important diagnostic markers for disease and prognostics if accompanied by an autoimmune-associated illness [87-91]. The most common classes of autoimmune diseases that cause MC and ICM are 
granulomatous and eosinophilic diseases are among the most common ADs capable of causing CM [8].

Connective tissue diseases are an import category of autoimmune diseases that can cause ICM. They are diseases typified by alterations in the cells and matrix that hold together body and tissues. The most common areas of manifestations are joints, muscle and the skin. They may also involve organs and organ system such as heart, lungs, kidney, blood vessels and eyes [92]. More than 200 diseases can affect connective tissues but ICM is common only in six diseases - systemic lupus erythematosus, rheumatoid arthritis, ankylosing spondylitis, scleroderma, dermatomyositis and periarteritis [8]. Although cardiac dysfunction such as global LV dysfunction, segmental LV wall motion abnormalities and RV enlargement are common complications in patients with connective tissue diseases, the development of ICM is not a frequent manifestation in the naturel history of the disease [93].

\section{Drugs/Toxins}

Drugs and toxins are an important cause of ICM because they are potentially reversible after the withdrawal of the causative drug or exposure to environmental toxins. Early detection of the condition is vital to withdraw the causative drug and to improve therapeutic outcomes to the patient, or to prevent the progression from MC to ICM or from ICM to heart failure. Prescription drug-induced ICM in particular, requires clinical attention because they reduce the efficacy of previously effective drugs recommended for the long-term management of common diseases as well as complicates patient management. The most frequent prescription drugs implicated as the major cause of ICM in clinical settings include anti-cancer (or chemotherapeutic) drugs including anthracyclines, cyclophosphamide trastuzumab and tyrosine kinase inhibitors because of their cytotoxic effects [94]. Other commonly used prescription drugs besides chemotherapeutic drugs that can cause ICM are antiretroviral drugs such as zidovudine, didanosine and zalcitabine, and antipsychotic drugs such as phenothiazines and clozapine [95].

Anti-cancer drugs, in particular anthracyclines, is a common prescription drug in the treatment of hematologic and solid malignancies. It has a direct cardiotoxic effect. Various anthracyclinebased drugs such as doxorubicin, daunorubicin, epirubicin, idarubicin, and mitoxantrones are effective and in common use in oncologic practice. The risk of anthracycline-induced ICM is dose dependent and the risk increases with increasing age [96-99]. Earlier clinical trials of adjuvant anthracycline therapy report the incidence of ICM is equal to or less than $2 \%$ but more recent evidence report about $10 \%$ to $50 \%$ of subclinical decline of LV ejection fraction (LVEF) greater than $10 \%$ following anthracycline treatment [100]. Earlier detection of anthracycline-induced LVEF changes is vital to minimize the incidence of clinical HF among cancer survivors. The changes in LVEF occurs between a month to one year following anthracycline treatment but there are cases of HF developing after six to twenty years after treatment $[96,97]$. With an increase in the population of cancer survivors of childhood cancer, increased detection rate of adult onset of ICM is increasing [101]. Additional risk factors for myocardial injury such as radiation, concomitant coronary artery disease and pre-existing cardiac function may complicate prognosis [101].

Antiretroviral drugs used in the treatment of HIV/AIDS is another important cause of MC and ICM. The use of these drugs is lifelong and their cardiotoxic properties accumulate and injure the myocardium. The initial reports of HIV-associated ICM emerged in the late 1980s and over time has become the leading non-infectious cause of death among
HIV-infected children [102-105]. The incidence of HIV-associated ICM increased significantly after the introduction widespread use of combined antiretroviral therapy suggesting the therapy may have additive effect on the development of ICM. The annual incidence of HIV-associated ICM in 2003 before the introduction of combined antiretroviral therapy was 15.9 per 1000 persons [106], which rose to 176 per 1000 persons in 2014 after the introduction of combined antiretroviral therapy [107]. Individual antiretroviral drugs such as zidovudine, didanosine or zalcitabine are also potential causes of ICM in HIV positive patients [108-111].

Antimalarial drugs mostly chloroquine, is another potential cause of therapy related drug-induced ICM. Chloroquine and its derivatives such as hydroxychloroquine is a common drug in the treatment of malaria as well as in rheumatoid arthritis, sarcoidosis, and systemic lupus erythematous [112]. Since chloroquine is known to induce a variety of other toxic effects such as retinopathy, neuropathy and myopathy, its cardiotoxic effect has not been appreciated. Cardiotoxic effects of chloroquine include conduction disturbances such as bundle branch block and biventricular hypertrophy in the presence of restrictive CM [113]. Since the use of chloroquine in the treatment of malaria has decreased as well as the global incidence of malaria, the cardiotoxic effects of chloroquine has not received much attention in scholarly discourse relative to chemotherapeutic and antiretroviral drugs.

Increasing evidence also associates the use of antipsychotic drugs with the development of ICM. In clinical setting, the recommendation of antipsychotic drugs for the treatment of schizophrenia and other multiple mental health conditions has increased the overall population exposed to these medications. Antipsychotic regimens have cardiotoxic properties and are associated with serious cardiovascular complications. They are secondary causes of inflammatory DCM, whose clinical features include diffuse myocardial damage, reduced cardiac contractility and HF [114]. Although several antipsychotic drugs may result in adverse metabolic and cardiovascular effects, only phenothiazines and clozapine therapies emerge as the major cause of drug-induced inflammation of the heart muscles contributing to the pathogenesis of ICM.

Besides prescription (or medical) drugs, non-medical drugs, generally termed as toxins, are another important cause of inflammation of the myocardium contributing to the pathogenesis of myocarditis and its long-term and severe sequela ICM. Whereas the intention of prescription drugs is to treat or manage a specific medical condition, non-medical drugs are recreational drugs whose consumption alters the mental conscious state or alleviates pain. Users of recreational drugs usually abuse them, that is, the consumption of drug causing dependency. Consumption of recreational drugs may lead to tolerance, the need to consume larger amounts of a drug to achieve the effects of previous consumption. Recreational drugs have different cardiac effects but lead to a common pathway to cause changes in myocardial morphology and function. The common categories of recreational drugs that can cause ICM are cardiodepressant such as ethanol, and cardiostimulants such as cocaine or amphetamines. In addition, acute or chronic exposure to environmental toxins such as heavy metals (cobalt, lead, mercury, arsenic, lithium or beryllium) and carbonaceous compounds (carbon monoxide or carbon tetrachloride) may also contribute to the pathogenesis of ICM [8]. 


\section{Pathophysiology}

\section{Infectious/Autoimmune ICM}

The pathophysiology of ICM due to infectious agents in humans remains to be elucidated. At present, the bulk of the evidence on pathophysiology of ICM relies on viral aetiologies based on studies on murine models. Consequently, the pathophysiologic mechanisms have been described in terms of host factors, viral entry, innate immune response, direct viral injury, and acquired immune response.

\section{Host susceptibility factors}

Inflammatory $\mathrm{CM}$ does not develop in all patients with the aetiologic viral infection suggesting host factors may play a role in the susceptibility of developing of ICM in some patients. The precise host factors are unclear although malnutrition, pregnancy, sex hormones and age may play a role in the susceptibility to ICM in patients infected with the causative infectious agent [115]. Genetic host factors such as histocompatibility haplotype, HLA-DQ and CD45 polymorphisms may contribute to the vulnerability to early viral infection [116-118]. Other factors that may predispose an individual to ICM through increased virus virulence include selenium deficiency, vitamin $\mathrm{E}$ deficiency and mercury exposure [119-120]. Viral factors such as genotype phenotype may also affect cardiovirulence [121].

\section{Viral entry into cardiomyocytes}

The pathophysiology of infectious and autoimmune myocarditis and ICM comes from murine models in which susceptible strains of mice are infected with cardiotropic virus mainly CVB. Virus enters the cardiomyocytes through endothelial receptors, most notably the coxsackie-adenovirus receptor (CAR) [123]. Besides CAR, coxsackievirus serotypes $\mathrm{B}_{1}, \mathrm{~B}_{3}$ and $\mathrm{B}_{5}$ use decay-accelerating factor and adenoviruses use $\alpha v$ integrins as co-receptors for viral entry [124-126]. Difference in binding to the decaying-accelerating factor increases viral virulence in CVB infections [127]. The brain and the heart has a high expression of CAR, with its peak in the perinatal period and subsequent overall levels decreasing with age [128]. In paediatric populations (immature heart), CAR occupies the entire surface of the cardiomyocytes. In contrast, in mature hearts in adults, CAR occurs predominantly in the intercalated disks [129]. The expression level and location of CAR in neonates and infants explains the susceptibility of these cohorts to CVB-mediated MC and ICM. A recent study involving CAR-inducible murine model demonstrated that CAR is the receptor for coxsackievirus in vivo and that the elimination of CAR blocked virus entry into cardiomyocytes as well as eliminated signs of ICM [130]. Previously, the general belief was that MC was a primary autoimmunemediated disease because of the presence of autoantibodies targeting cardiomyocyte proteins in myocarditis patients [131]. However, the lack of myocardial injury in a model of CAR mice suggested that the primary mechanism might be viral-mediated at least in the acute phase [23].

\section{Innate immune response}

Innate immune response is the non-specific defence mechanisms activated immediately or within hours after the appearance of antigen in the body, and may play a role in the pathogenesis of viral-associated ICM. The intensity and duration of the innate immune response to viral infection plays a major role in the pathogenesis of ICM. Innate immune response upregulates a number of inflammatory mediators such as tumour necrosis factors (TNF), nitric oxide, toll-like receptors and complement. Murine models demonstrate that these mediators play a dual role in the pathogenesis of viral-induced ICM. Increased TNF levels decreased viral load but also led to exaggerated immune response and late mortality [132]. Nitric oxide not only inhibits viral replication but also contributes to the pathogenesis of ICM by enhancing ongoing myocardial injury [133,134]. Toll-like receptors and myeloid differentiation factor-88, an adapter molecule for tolllike receptors, minimize viral replication in the heart but myeloid differentiation factor- 88 appears to significantly affect the severity $[135,136]$. Complement amplifies both the innate and adaptive immune responses, increases susceptibility to autoimmune myocarditis and progression to chronic ICM [137].

\section{Direct viral injury}

Innate immune response does not always eliminate all the viruses. Those that evade the response by the innate immunity replicate and produce viral proteins causing a direct injury to the myocardium. In a murine model with severe immune deficiency, CVB3 infection results in myocardial injury [138]. Picornavirus protease 2A inhibits protein synthesis in host cells and CVB3 protease $2 \mathrm{~A}$ has proteolytic activity, cleaving protein dystrophin in host protein inducing ICM $[116,139,140]$. In addition, CVB3 proteases $2 \mathrm{~A}$ and $3 \mathrm{C}$ can also induce cell apoptosis, which aggravates cardiomyocyte injury [141]. In patients with virus-associated ICM, the inhibition of viral proteases could be a potential novel target in the treatment of viral-induced ICM.

\section{Cell-mediated immune response}

Cell-mediated immune response leads to an indirect injury to the infected myocardium. Cell-mediated response does not involve antibodies. Cell-mediated immunity is involved in the pathogenesis of viral and autoimmune myocarditis and ICM. Inflammatory infiltrates found in myocardial lesions of myocarditis consists of more than $70 \%$ of mononuclear, primary monocytes, macrophages and T lymphocytes [142]. In experimental autoimmune myocarditis mice model, the inhibition of monocyte chemoattractant protein 1 and macrophage inflammatory protein reduced the severity and prevalence of myocarditis [143]. In susceptible mice, helper T cells (TH1\&2) produce cytokines (TNF and interleukins), which contribute to the development of autoimmune CM within 6-12 hours of viral infection. In addition, TH17 produces interleukin-17 that results in the development of severe autoimmune MC in interferon $\gamma$ deficient experimental autoimmune mice [144].

Inhibiting the proliferation and activation of $\mathrm{T}$ lymphocyte in experimental autoimmune mice reduces the immune responses and the severity of MC [145]. Acute injury to the myocardium activates the adaptive immune response, which further mediates cardiac injury. $\mathrm{CD} 4^{+} \mathrm{T}$ lymphocytes contribute to the pathogenesis of autoimmune $\mathrm{MC}$ through production of key cytokines, and antibodies and autoantibodies [146-148]. Rodent models of CVB3-induced autoimmune MC develop antibodies targeting multiple cardiac antigens [149]. In MC and ICM patients, autoantibodies targeting several different cardiac antigens have been observed and precede the development of ICM [150-152]. Particularly, serum of patients with MC and ICM have antibodies targeting cardiac beta-1 adrenergic receptors and the elimination of circulating beta-1-adernergic receptors autoantibody by immunoabsorption improve cardiac function [153-155]. Antibodies targeting Tnl result in severe myocardial inflammation and fibrosis in mice models causing myocardial dilation and reduced survival but those targeting TnT do not exhibit similar immunologic response [156-158]. In a majority of virus-associated MC and ICM, the innate immune system eliminates the virus with no subsequent adverse effects but 
in a minority of patients, the virus persists leading to cardiomyocyte injury, and myocardial inflammation secondary to immune response to cardiac autoantibodies.

\section{Drug/Toxin ICM}

Pathophysiology of drug/toxin-associated ICM has been described in the light of anti-cancer drugs, in particular anthracyclines and trastuzumab. The major mechanisms of anthracycline-associated ICM is the formation of anthracycline-iron complexes and the stimulation of free radical formation [159-162]. In human cardiomyocyte is susceptible to injury by free radical because it has lower concentration (4 times less) of superoxide dismutase, and 150 times less catalase compared to the liver [163]. Superoxide dismutase is an enzyme that contributes to the breakdown on harmful oxygen molecules in cells, while catalase speeds up the decomposition of hydrogen peroxide into molecular oxygen and water. Anthracycline also supresses the actions of enzyme glutathione peroxidase, which is the principle cardiomyocyte defence against freer radical damage. Glutathione peroxidase is a cytosolic enzyme that increases the rate of decomposition of hydrogen peroxide into water and oxygen, and the reduction of peroxide radicals into alcohol and oxygen [164]. Defective enzymatic actions leads to the accumulation of superhydroxide free radicals, which leads to severe lipid peroxidation. The result is the destruction of mitochondrial membranes, endoplasmic reticulum and nucleic $[165,166]$. Mitochondrial biogenesis and the formation of reactive oxygen species (ROS) may also contribute to the development of ICM [167]. Other mechanisms include reduced production of adenosine triphosphates, inhibited nucleic acid and protein synthesis, dysfunctional mitochondrial synthesis, cardiomyocyte apoptosis and increased immune functions $[168,169]$.

\section{Clinical evaluation and management}

\section{Clinical manifestation}

Signs and symptoms: Inflammatory CM has heterogeneous and non-specific cardiac signs and symptoms based on the degree of myocardial inflammation and LV dysfunction. Clinical manifestation varies from an asymptomatic course of a mild ongoing disease with mild myocardial impairment to a fulminant $\mathrm{HF}$ accompanied by malignant arrhythmias [8]. Sometimes, cardiac death may be the first and the only manifestation of the disease in previously healthy individuals. Initial viral infection in MC patients can be subclinical, and thus, its absence in patient history does not exclude the development of ICM. In mild cases of MC, symptoms during the acute phase are less dramatic but does not imply favourable long-term prognosis. However, the degree of myocardial injury during the acute phase of infection is still a key factor determining the recovery of LV function in the subsequent phases $[1,8]$.

Inflammatory CM should be suspected in previously asymptomatic young persons with some coronary disease risk factors, and days or weeks following respiratory or gastrointestinal viral syndromes in the absence or presence of elevated systemic inflammatory markers, fever and cardiac signs (dyspnoea or orthopnoea, or palpitations, or effort intolerance or chest pain) or unobstructed coronary arteries at coronary angiography [170]. Biopsy-proven MC may also present with arrhythmias, syncope or aborted sudden cardiac death (SCD), subacute or chronic HF or new-onset acute HF and/or cardiogenic shock [170]. MC may cause or be a complication of peripartum CM or Takotsubo $\mathrm{CM}$. Fulminant MC can have viral prodrome a month prior to the onset of cardiac symptoms, onset of unexplained HF, hemodynamic compromise and a general good prognosis [4]. Since MC can mimic many non-inflammatory pathologies, the exclusion of other potential causes such as valvular heart disease, pericardial constriction and coronary artery disease may be important to confirm diagnosis [170].

Reasons for physician's visit: Heart failure (HF) is a common manifestation of MC/ICM and a leading reason for a physician visit. It may manifest with a gradual onset and mild symptom but can also manifest acutely ending in cardiogenic shock, in which mechanical circulatory device support or cardiac transplantation is the most effective therapy to save life. Acute onset of HF is common in fulminant MC. Patient who survive the acute phase, exhibit significant improvement or a complete normalization of LV systolic function with favourable long-term prognosis in a few weeks [4]. Spontaneous improvement of LV function or following HF therapy is common to a certain extent to almost $50 \%$ of MC with initial systolic dysfunction [170-174]. As a result, it is prudent to postpone long-term therapeutic decisions such as cardiac implantation or implantation of cardioverter or defibrillator for about 3 to 6 months after disease onset or after initiation of therapy.

Diastolic dysfunction, although rare, can also manifest in some patients with virus-associated ICM, and is another common reason for a visit to the physician. In a recent 6-month follow-up study reports, a decline in myocardial inflammatory infiltration correlated with improvement in a number of echocardiographic parameters and functional status with a reduction in cardiac troponin levels [175]. The evidence of the involvement of diastolic dysfunction in viral (PVB19)associated MC and ICM have also been reported [176]. The basis of this evidence is the presence of impaired function of the endothelium in individuals with infected endothelial cells associated with a higher incidence of chest pain as a clinical feature of the disease [176]. The utility of EMB in isolated diastolic dysfunction is unclear due to the lack of evidence for the introduction of a specific regimen based on positive bioptic findings of MC. Besides diastolic dysfunction, another clinical presentation of ICM by chest pain mimicking anginal pectoris or a pericarditis-like character, especially in the presence of perimyocarditis. In these patients, especially with elevated markers for myocardial injury, the main reason for sending them to the catheterization laboratory is to exclude acute coronary syndrome. Normal coronary arteries and the absence of other pathologies including aortic dissection, atrial or ventricular tachycardia increases the clinical suspicion of MC [177].

The third common reason for a physical visit for suspected ICM are symptoms associated with supraventricular and ventricular arrhythmias. The presence of conduction disturbances or severe ventricular arrhythmias raise the clinical suspicion for GCM, cardiac sarcoidosis or Borrelia burgdorferi as the aetiologic agents. MC has been discovered incidentally at autopsy in a few cases of patients who died suddenly probably due to malignant arrhythmias. However, more frequently, a mild course marked by palpitation, dizziness or syncope alerts the possibility of the presence of serious arrhythmias [170].

The symptoms of MC and ICM can manifests simultaneously or at different phases of the disease. Patients exhibiting symptoms of HF usually have a poorer prognosis compared to those presenting with cheat pains or arrhythmias [22]. Peripartum CM could be considered in ICM patients a few months before and after delivery $[8,22]$. Peripartum CM presents with systolic HF in previously healthy women towards the end of pregnancy or a few months after birth, with a preponderance for women of an African descent. Although the causes of peripartum $\mathrm{CM}$ have not been definitively clarified, the involvement of MC in its pathogenesis or as a complication has been suggested $[1,8,10]$. 


\section{Clinical evaluation}

Diagnostic criteria: The diagnosis of MC and ICM have remained a clinical challenge. Today, despite advancements and wide availability of non-invasive imaging modalities, the diseases remain a diagnosis per exclusionem. The ESC Working Group in myocardial and pericardial diseases and AHA diagnostic and treatment strategies for specific DCM raise clinical suspicion for MC and ICM based on the presence of HF chest pain and arrhythmias, and evidence of cardiac dysfunction based on non-invasive $[8,10]$. The diagnosis of $\mathrm{MC}$ is suspected in the presence of $\geq 1$ clinical presentation and $\geq 1$ diagnostic criterion or $\geq 2$ diagnostic criteria, if the patient is asymptomatic (Figure 2).

The ESC recommends EMB for all patients fulfilling the diagnostic criteria and remains the gold standard diagnostic tool for ICM. Unfortunately, the use of EMB is uncommon in clinical settings and the method of first choice only in specialized centres with the expertise and experience and advanced laboratory equipment for complex evaluation of EMB samples [170].

Diagnostic workout: Diagnosis of ICM is a clinical challenge due to the lack of pathognomonic features. The disease lacks clinically available and specific blood tests to confirm diagnosis. Serum markers of inflammation such as erythrocyte sedimentation rate and C-reactive protein are non-specific but could be elevated in patients with acute and critical disease. Troponin I is elevated in about $34 \%$ of acute MC patients with an average of one month of symptoms [178]. The ESC position statement on HF recommends troponin assessment in clinically suspected MC as well as natriuretic peptides and other biomarkers [10]. A 12-lead ECG is recommended in all suspected cases of MC. Although its findings are non-specific, findings such as rhythm disorders such as ventricular tachycardia or AV block may suggest GMC or cardiac sarcoidosis associated MC [1]. The ESC also recommends echocardiography in the setting of suspected MC for risk stratification and prognostication or the exclusion of other potential pathologies [10]. A QRS width $>120 \mathrm{~ms}$ predicts a higher risk of death or cardiac transplantation [178]. PR-segment depression and diffuse ST-segment elevation suggests pericarditis whereas low voltage in the presence of hypertrophied LV walls in the absence of an infiltrative disorder such as amyloidosis may suggest myocardial oedema [8].

Cardiac magnetic resonance imaging (MRI) can distinguish ischemic from non-ischemic CM based on the pattern of myocardial injury on T1-weighted, late gadolinium enhancement (LGE) [179].
In ischemic CM, LGE shows increased endocardial signal intensity in coronary distribution whereas in MC the pattern of LGE is usually epicardial or in the midwall. Non-contrast enhanced T2-weighted sequences and post-gadolinium T1-weighted sequences are used to separately or in combination with LGE to diagnose MC [179]. T1 and T2 mapping increase sensitivity and reduce artefacts respectively $[180,181]$. The presence of LGE in biopsy proven viral MC can predict the risk of ventricular arrhythmias and cardiovascular death. The diagnosis of cardiac MRI features of acute MC can evolve from focal to diffuse pattern and can resolve [182]. Although the confirmation of MC requires histological or immunohistological evaluation, EMB remains the gold standard diagnostic tool. However, the 2013 ACCF/AHA guideline on the management of HF [183] and the 2013 ESC position statement have inconsistent recommendation regarding indications for EMB [10]. The ESC recommends a broader use of EMB for the diagnosis and management of $\mathrm{MC}$ based on the presence or absence of viral genomes and inflammation. However, EMB is usually recommended when GCM was likely or lymphocytic MC is suspected in the setting of fulminant HF [184]. In general, EMB should be performed after histological information can influences prognosis or guide treatment.

\section{Clinical management}

The AHA scientific statement on diagnostics and treatment of specific forms of DCM recommends the treatment of inflammatory DCM should follow the current guidelines for the treatment of systolic HF [183,185]. Immunosuppression is usually not indicated for the management of acute lymphocytic MC in adults. In the case of GCN, cardiac sarcoidosis or eosinophilic MC, treatment targeting the modification of the immune response can be considered $[10,186]$. Sustained aerobic exercise is contraindicated during acute viral MC because of increased risk of sudden death. Competitive sport should be avoided for 3 to 6 months after diagnosis of MC. Non-steroidal anti-inflammation drugs should be avoided due to increased risk of inflammation and mortality [8]. Acute arrhythmia management is supportive since arrhythmias often resolve with resolution of acute inflammation. In patients with drug-refractory ventricular arrhythmias after MC, endocardial and epicardial radiofrequency, catheter ablation can be effective [187]. Some MC patients who develop cardiogenic shock despite optimal medical management may requires mechanical circulatory support (MCS). The role of immunosuppression in patients who require MCS has not been evaluated systematically and remains uncertain. The overall rate of survival following heart transplantation

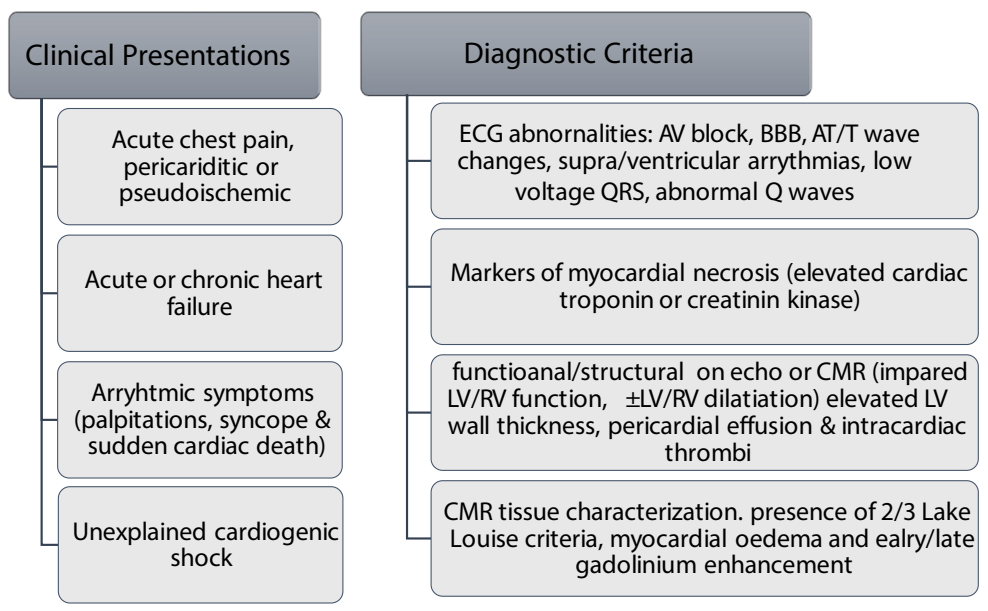

Figure 2. Diagnostic criteria for clinically suspected myocarditis 
for adult MC patients is same to that of other aetiologies of HF but a higher post-transplantation risk if active MC is present in the transplanted heart $[188,189]$.

\section{Diagnosis/Management: A meta-analysis}

Clinical evaluation and management of ICM lacks definitive methods and specific treatment methods respectively. Variable and non-specific clinical presentation, including heterogeneity of aetiologic agents complicates diagnosis and management. Diagnosis per exclusionem and variable therapeutic interventions based on the causative agent have been described in literature. Although EMB is the diagnostic gold standard that can also determine the causative agent, its recommendation for diagnostic varies across guidelines. Besides, the current ESC and AHA guidelines recommend the utility of EMB only in centres with the requisite expertise and experience because of the associated high risks of complications $[8,10]$. The limited utility of EMB in routine clinical practice might undermine efficacious clinical management approaches because it is the only reliable method for detecting and quantifying myocardial viral presence and providing valuable information for the selection of the most appropriate therapy.

Standard HF regimens have proved beneficial for ICM patients but in a subset of ICM patients with no evidence of cardiac dysfunction or with refractory symptoms despite optimal medical treatment, a safe and effective treatment remains a major clinical challenge. Antiretroviral drugs for viral-associated ICM, which targets to eliminate virus in the acute phase in most cases are in appropriate since most patients presenting in hospitals are past the acute phase, in the chronic phase of the disease [12]. The use of immunosuppression therapies such as immunomodulation and immunosuppression have not been recommended because of insufficient evidence from clinical trials. However, immunosuppression may be a promising adjuvant therapy to the standard HF therapy in selected cases of autoimmune disease such as ICM patients with virus-negative myocardium or those with persistent HF symptoms greater than six months despite optimal medical therapy $[190,191]$. Thus, the present meta-analysis seeks to determine the common methods used in the diagnosis and management of ICM in routine clinical practice. The search strategy, study selection, data extraction and analyses were performed according to the PRISMA guidelines for systematic review and meta-analysis [192]. In total, 14 studies that evaluated diagnostic and management of ICM patients formed the final dataset for analysis (Table 1).

\section{Findings}

Fourteen studies evaluating the diagnosis and/or management of ICM formed the final dataset for analysis in the present meta-analysis [193-206]. Eight (8) of the studies were randomized prospective clinical trials $[196,197,199-203,206]$ and the remaining were non-randomized prospective or retrospective studies [193-195,198,204,205]. In total, the 14 studies enrolled 503 patients suspected with MC with cardiac involvement or ICM. Despite the uncommon use of EMB in routine clinical practice and in non-specialized centres, all the included clinical trials relied on EMB for a definitive diagnosis of MC/ICM. The most common non-invasive imaging for ICM diagnosis in the included studies is echocardiography. Its main use was to demonstrate cardiac dysfunction and to exclude other potential causes of cardiac symptoms other than MC. Moreover, echocardiography has been used

Table 1. Summary of studies included in the meta-analysis

\begin{tabular}{|c|c|c|c|c|c|c|c|}
\hline 1st Author (Year) [Ref \#] & Study Design & Sample & Patients/ Diagnosis & LVEF (Baseline) & LVEF (FuP) & FuP Period & Immunosuppressive Drugs \\
\hline Chan (1991) [193] & $\begin{array}{l}\text { Retrospective Non- } \\
\text { randomized }\end{array}$ & 13 & $\begin{array}{c}\text { Biopsy-proven MC } \\
+\mathrm{HF}\end{array}$ & $34 \pm 12$ & $66 \pm 7$ & $14 \pm 11$ & Prednisone + azathioprine \\
\hline Escher (2016) [194] & $\begin{array}{l}\text { Retrospective Non- } \\
\text { randomized }\end{array}$ & 53 & $\begin{array}{c}\text { Biopsy-proven virus(- } \\
\text { ve) ICM }\end{array}$ & $29.3 \pm 8.8$ & $41.7 \pm 13.2$ & 6.0 & $\begin{array}{l}\text { Prednisone }+ \text { azathioprine for } \\
\qquad 6 \text { months }\end{array}$ \\
\hline Frustaci (2003) [195] & $\begin{array}{l}\text { Retrospective responders vs. } \\
\text { non-responders }\end{array}$ & 21 & $\begin{array}{c}\text { Virus -ve, active } \\
\text { lymphocytic MC } \\
+ \text { HF }\end{array}$ & $25.7 \pm 4.1$ & $47.1 \pm 4.4$ & 6.0 & $\begin{array}{l}\text { Prednisone }+ \text { azathioprine for } \\
6 \text { months }\end{array}$ \\
\hline Frustaci (2009) [196] & $\begin{array}{l}\text { Randomized placebo } \\
\text { controlled }\end{array}$ & 43 & Virus -ve ICM & $26.5 \pm 6.7$ & $45.6 \pm 9.6$ & 6.0 & $\begin{array}{l}\text { Prednisone }+ \text { azathioprine for } \\
6 \text { months }\end{array}$ \\
\hline Gullestad (2001) [197] & $\begin{array}{l}\text { Randomized to IVIG of } \\
\text { placebo }\end{array}$ & 19 & $\mathrm{ICM}+\mathrm{HF}$ & $26 \pm 2$ & $31 \pm 3$ & 6.5 & $\begin{array}{c}\text { Intravenous immunoglobulin } \\
\text { (IVIG) }\end{array}$ \\
\hline Kuhl (2003) [198] & $\begin{array}{l}\text { Retrospective Non- } \\
\text { randomized }\end{array}$ & 22 & $\begin{array}{c}\text { Viral +ve } \\
\text { myocardium + LV } \\
\text { dysfunction }\end{array}$ & $44.7 \pm 15.5$ & $53.1 \pm 16.8$ & 6.0 & Interferon (IFN)- $\beta$ therapy \\
\hline Mason (1995) [199] & Randomized controlled & 64 & $\begin{array}{l}\mathrm{MC}+\text { onset of } \mathrm{HF} \\
<2 \text { years preceding } \\
\text { enrolment }\end{array}$ & $25 \pm 10$ & $34 \pm 20$ & 6.0 & $\begin{array}{c}\text { Prednisone }+ \text { cyclosporine or } \\
\text { azathioprine }\end{array}$ \\
\hline McNamara (2001) [200] & $\begin{array}{l}\text { Prospective placebo } \\
\text { controlled }\end{array}$ & 10 & $\begin{array}{l}\text { Recent onset DCM } \\
\text { with Inflammation }\end{array}$ & $25 \pm 8.0$ & $49 \pm 19$ & 12.0 & Intravenous immune globulin \\
\hline Merken (2018) [201] & Randomized controlled & 90 & Echo/EMB & $28 \pm 10$ & $44 \pm 13$ & 7.2 & $\begin{array}{l}\text { Azathioprine }+ \text { prednisone } \pm \\
\text { cyclosporine }\end{array}$ \\
\hline Parrillo (1989) [2002] & Prospective RCT & 49 & $\mathrm{DCM}+\mathrm{HF}$ & $17.9 \pm 1.0$ & $22.2 \pm 1.6$ & 3.0 & Prednisone \\
\hline Staudt (2001) [203] & $\begin{array}{l}\text { Randomized crossover IA } \\
\text { to IG }\end{array}$ & 12 & $\begin{array}{c}\text { DCM + Evidence } \\
\text { of myocardial } \\
\text { inflammation }\end{array}$ & $21.3 \pm 1.7$ & $27.0 \pm 1.3$ & 3.0 & $\begin{array}{l}\text { IA and subsequent IgG } \\
\text { substitution }\end{array}$ \\
\hline Weinmann (2017) [204] & Prospective Non-randomized & 35 & $\begin{array}{l}\text { Post-inflammatory } \\
\mathrm{CM} \text { and HF }\end{array}$ & $26.7 \pm 1.1$ & $40.6 \pm 1.8$ & $12.2 \pm 1.8$ & $\begin{array}{c}\text { Immunoadsorption with } \\
\text { subsequent IVIG substitution }\end{array}$ \\
\hline Weinmann (2019) [205] & Prospective Non-randomized & 31 & $\begin{array}{l}\text { DCM patients on } \\
\text { immunosuppression }\end{array}$ & $28.0 \pm 0$ & $42.0 \pm 0$ & 30.5 & $\begin{array}{l}\text { Immunoadsorption and } \\
\text { subsequent IVIG }\end{array}$ \\
\hline Wojnicz (2001) [206] & $\begin{array}{l}\text { Randomized to } \\
\text { immunosuppression or } \\
\text { placebo }\end{array}$ & 41 & $\begin{array}{l}\text { DCM + Myocardial } \\
\text { inflammation + HF }\end{array}$ & $23.8 \pm 8.6$ & $39.5 \pm 10.7$ & 6.0 & Azathioprine + prednisone \\
\hline
\end{tabular}

DCM: Dilated Cardiomyopathy; EMB: Endomyocardial Biopsy; FuP: Follow up Period; HF: Heart Failure; IA: Immunoadsorption; ICM: Inflammatory Cardiomyopathy; IVIG: Intravenous Immunoglobulin; LVEF: Left Ventricular Ejection Fraction; MC: Myocarditis 
on the evaluation of the therapeutic efficacy based on the effect of immunosuppression therapy on cardiac structure and function.

Across all the included studies, there was common inclusion (diagnosis) criteria for ICM. (a) The confirmation of MC based on histologic and immunohistochemical evidence of myocardial inflammation. (b) Evidence of cardiac dysfunction based on LVEF $\leq$ $40-45 \%$, and (c) The absence of other potentially known aetiologies of HF such as hypertension, significant coronary disease, valvular disease, endocrine disease, significant renal disease and drug/alcohol abuse. Besides diagnosis, other two common requirements for patients' enrolment was eligibility for immunosuppression therapy. Chronic HF lasting for more than 6 months that is unresponsive to optimal medical therapy and the absence of cardiotropic viruses at polymerase chain reaction analysis, meaning virus-negative MC or ICM.

The most common immunosuppression therapy given to ICM patients is azathioprine later substituted with prednisone for about six months. The most common cardiac feature evaluated to determine therapeutic effectiveness is changes on LVEF between baseline and at follow-up. The findings reveal that immunosuppression has a beneficial effect on virus negative ICM patients. The use of immunosuppression drugs demonstrated significant improvement after six months. The weighted mean difference (WMD) between pre- and postimmunosuppression treatment was $13.71 \%$ (95\% CI: 10.39 to 17.03 ; $\mathrm{p}=0.000$; Figure 3 ). The safety of immunosuppression could not be determine since very few studies evaluated the adverse effects of the drug on the heart or hard clinic endpoint such as death and the need for cardiac transplantation. Furthermore, upcoming studies should focus on clarifying the value of immunosuppression as well as evaluate immunosuppression with placebo or with traditional HF regimens to determine the independent effect of immunosuppression on cardiac function.

\section{Discussion}

From the data collected, there is some evidence that the use of immunosuppression therapy in a subset of ICM patients (those with biopsy-proven virus-negative myocardium and HF symptoms $>6$ months) may lead to short-term improvement (3 to 12 months) in cardiac function based on echocardiographic findings of a mean increase of 13 percentage points in LVEF. The improvement was significantly better compared to placebo. The effectiveness of the therapy in the long-term was demonstrated in two studies suggesting the short-term benefit persisted in the long term $[194,206]$. However, the two studies used immunohistological marker of inflammation (upregulation of HLA) to diagnose MC, which could explain the longterm effect of immunosuppression on LV systolic function. The use of conventional histological biopsy criteria are insensitive and nonspecific for detecting persistence immune damage and may not be very effective in guiding the use of immunosuppressive therapy. Thus, at present heart transplantation remains the sole treatment for ICM patients with HF that can lengthen survival. The data was insufficient to quantify the effect of immunosuppression therapy on safety - adverse effects of the drug on cardiac function or heart transplantation free survival, as well as on therapeutic effectiveness - the rate of mortality, hospitalization and/or heart transplantation. Additional studies would be warranted to confirm both the short- and long-term safety and efficacy of immunosuppression in these patients.

The present meta-analysis only evaluated viral-associated ICM although the disease has heterogeneous aetiology including fungi, protozoa and parasites as infectious agents, and toxins and drugs as non-infectious causes. The use of immunosuppressive therapy in nonviral aetiologies has not been conclusively demonstrated and its use is thus not recommended in present clinical guidelines. Viral-associated ICM progresses in three phases - viral infection, autoimmunity and inflammatory DCM - that may be separate of chronologically overlap. Viral invasion may persist into the second and third phases of the disease and thus can result in HF by ongoing replication with direct immune mediated injury or by non-infectious transcriptional expression. Thus, specific diagnostic criteria that incorporated new techniques including immunohistochemistry, polymerase chain reaction and in situ hybridization can improve diagnosis as well as detect the specific phase of the disease, and elucidate effective treatment for ICM. At present, there is lack of evidence suggesting that immunosuppression could improve survival in ICM patients. in an earlier review, immunosuppression therapy has not proved effective in reducing all-cause death and heart transplantation in patients with

\section{Difference in Means between Pre- and Post-Immunosuppression Treatment}

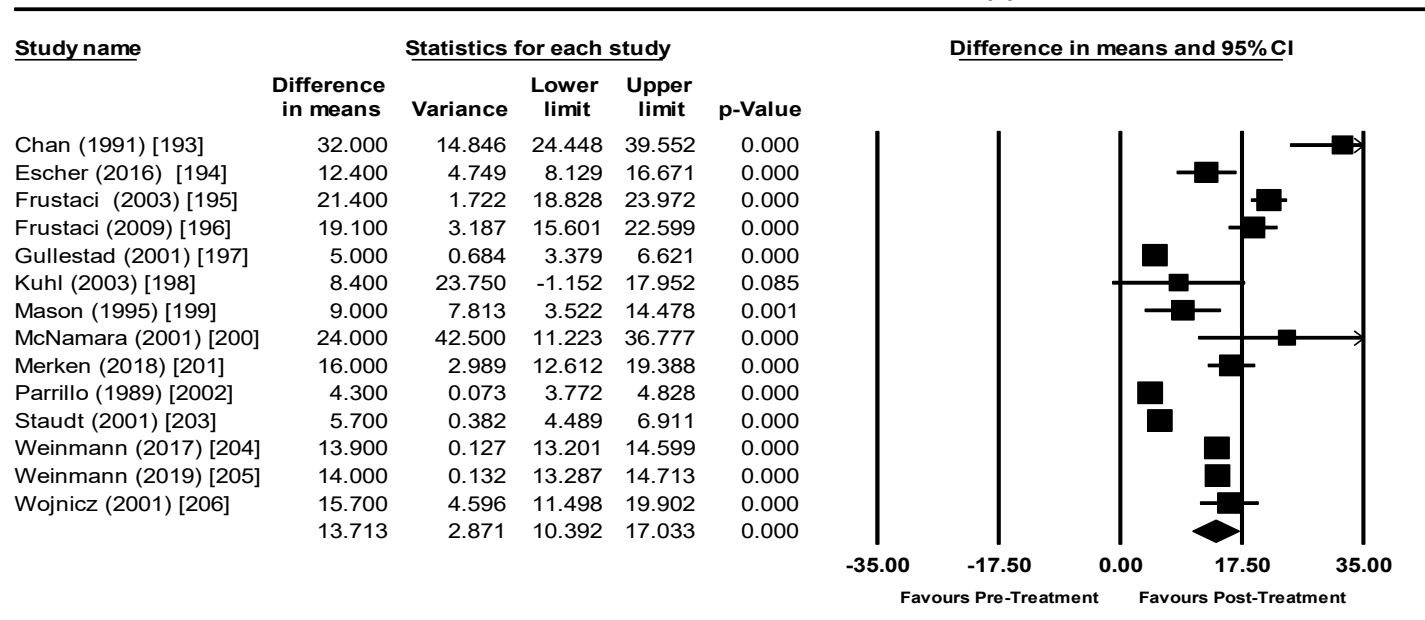

Heterogeinity: $Q=2.70 ; \operatorname{df}(Q)=3(p=0.442) ;$ Inconsistency $(I-S q u a r e d)=0.000 \%$

Figure 3. Forest plot of difference in means of pre- and post-treatment LVEF 
acute MC and HF and the use of immunosuppression is limited to supportive measures [207].

A recent systematic review and meta-analysis on immunomodulatory treatment for lymphocytic myocarditis does not support the use of immunosuppression in traditional lymphocytic MC patients, since it confer no clinical beneficial value. However, the analysis reported combined immunosuppression might be beneficial to a subset of $\mathrm{MC}$ and HF patients especially histologically proven virusnegative MC [208]. Although the included studies reports improvement in LVEF with the use of immunosuppressive therapy, the results should be interpreted with caution since $58 \%$ of adults with acute MC may recover spontaneously [209]. The choice of treatment regimen appears to determine the overall outcome, with different treatment regimens resulting in different outcomes. The present analysis pooled together the results of various regimens to provide a valuable insight into the overall effectiveness of immunosuppressive therapy on ICM patients. However, a statistically significant treatment outcome of one regimen may be diluted by the results of a less efficacious regimen. Thus, in future, a large and long-term clinical trial of a specific regimen should clarify the effect of individual or a combination of regimen and guide the selection of the most effective treatment regimen. The time of initial of therapy and the duration of a combined therapy of prednisone and azathioprine was not explicitly stated in some studies.

\section{Clinical implications}

Until now, no aetiologic-specific treatment for chronic HF secondary to ICM is available. Treatment largely focuses on guidelinedirected treatment of HF and arrhythmia complemented by supportive care. Although the modulation of autoimmune response in ICM caused by maladaptive hyper-immune response to infectious agents suggest beneficial effects on cardiac function in a subset of patients, the limited availability of RCTS testing this hypothesis reflects an immature state of the current clinical evidence. In the course of the present meta-analysis, 14 trials were included that evaluated the effect of immunosuppression on a subset of ICM patients with biopsy-proven virus-negative myocardium and HF symptoms greater than six months. ICM patients with HF symptoms less than six months were exclude because of the potential of spontaneous recovery of LV function. Due to wide heterogeneity of outcomes evaluated in individual studies, pooled effect of LVEF was assessed a surrogate marker for therapeutic effectiveness. The data shows that immunosuppression therapy may be beneficial for ICM patient with virus negative myocardium and HF symptoms greater than six months. However, future studies should clarify the long-term efficacy of immunosuppressive therapy in these patients, as well as other hard clinical endpoints such as hospitalization, cardiac transplantation and death.

\section{Conclusion}

Inflammatory $\mathrm{CM}$ is a form of dilated $\mathrm{CM}$ characterized by an inflammation of the myocardium, which is a long-term complication of myocarditis. Heterogeneity of aetiologic agents ranging from infectious (virus, fungi, protozoa and parasites) to non-infectious agents (autoimmune diseases and drugs/toxins) and a wide clinical presentation ranging from subclinical disease or asymptomatic forms to severe fulminant disease complicates epidemiology, diagnosis and management. Moreover, host factors such as genetics, age and gender may also affect disease manifestation and progression further complicating diagnosis and management. The major pathophysiologic mechanisms include invasion by infectious agents, innate immune response, and cell-mediated immune response. Diagnosis remains a challenge because of non-specific signs and symptoms. Although EMB remains the diagnostic gold standard, its use is reserved for specialized centres and thus unavailable for routine clinical practice. On cardiac MRI, the pattern of myocardial injury on T1-weighted and late gadolinium enhancement (LGE) may suggest MC. Echocardiography and ECG findings are non-specific although they are useful for the exclusion of other known aetiologies of HF. Biomarkers of myocardial inflammation such as troponin are non-specific although are elevated in acute MC. Finally, ICM lacks specific aetiologic treatment. The present treatment approaches are based on a combination of guideline directed HF regimen and supportive care such as immunosuppression. However, immunosuppressive therapy may have short-term clinical benefits in terms of the improvement of cardiac function for a subset of ICM patients with biopsy-proven virus negative myocardium and HF symptoms greater than six months. However, in these patients, the long-term treatment safety and effectiveness of immunosuppressive therapy has not been demonstrated.

\section{References}

1. Krejci J, Mlejnek D, Sochorova D, Nemec P (2016) Inflammatory cardiomyopathy: a current view on the pathophysiology, diagnosis, and treatment. Biomed Res Int 2016: $1-11$ [Crossref]

2. Parrillo JE (2001) Inflammatory cardiomyopathy (myocarditis): which patients should be treated with anti-inflammatory therapy? Circulation 104: 4-6. [Crossref]

3. Parrillo JE (1998) Myocarditis: how should we treat in 1998? J Heart Lung Transplant 17: 941-944. [Crossref]

4. McCarthy RE, Boehmer JP, Hruban RH, Hutchins GM, Kasper EK, et al. (2000) Long-term outcome of fulminant myocarditis as compared with acute (nonfulminant) myocarditis. N Engl J Med 34: 690-695. [Crossref]

5. Aretz HT, Billingham ME, Edwards WD (1986) Myocarditis. Am J Cardiovasc Pathol 1: 3-14. [Crossref]

6. Elliott P, Andersson B, Arbustini E, Bilinska Z, Cecchi F, et al. (2007) Classification of the cardiomyopathies: a position statement from the European Society of Cardiology Working Group on Myocardial and Pericardial Diseases. Eur Heart J 29: 270-276. [Crossref]

7. Maron BJ, Towbin JA, Thiene G, Antzelevitch C, Corrado D, et al. (2006) Contemporary definitions and classification of the cardiomyopathies: an American Heart Association scientific statement from the council on clinical cardiology, heart failure and transplantation committee; quality of care and outcomes research and functional genomics and translational biology interdisciplinary working groups; and council on epidemiology and prevention. Circulation 113: 1807-1816. [Crossref]

8. Bozkurt B, Colvin M, Cook J, Cooper LT, Deswal A, et al. (2016) Current diagnostic and treatment strategies for specific dilated cardiomyopathies: a scientific statement from the American Heart Association. Circulation 134: e579-e646. [Crossref]

9. Dominguez F, Kühl U, Pieske B, Garcia-Pavia P, Tschöpe C (2016) Update on myocarditis and inflammatory cardiomyopathy: reemergence of endomyocardial biopsy. Rev Esp Cardiol (Engl Ed) 69: 178-187. [Crossref]

10. Caforio AL, Pankuweit S, Arbustini E, Basso C, Gimeno-Blanes J, et al. (2013) Curren state of knowledge on aetiology, diagnosis, management, and therapy of myocarditis: a position statement of the European Society of Cardiology Working Group on Myocardial and Pericardial Diseases. Eur Heart J 34: 2636-2648. [Crossref]

11. Caforio AL, Calabrese F, Angelini A, Tona F, Vinci A, et al. (2007) A prospective study of biopsy-proven myocarditis: Prognostic relevance of clinical and aetiopathogenetic features at diagnosis. Eur Heart J 28: 1326-1333. [Crossref]

12. Schultheiss HP, Kuhl U, Cooper LT (2011) The management of myocarditis. Eur Heart $J$ 32: 2616-2625. [Crossref]

13. Kindermann I, Barth C, Mahfoud F, Ukena C, Lenski M, et al. (2012) Update on myocarditis. J Am Coll Cardiol 59: 779-792. [Crossref]

14. Richardson P (1996) Report of the 1995 World Health Organization, International Society and Federation of Cardiology Task Force on the definition and classification of cardiomyopathies. Circulation 93: 841-842. [Crossref]

15. Felker GM, Hu W, Hare JM, Hruban RH, Baughman KL, et al. (1999) The spectrum of dilated cardiomyopathy. The Johns Hopkins experience with 1,278 patients. Medicine 78: 270-283. [Crossref] 
16. Towbin JA, Lowe AM, Colan SD, Sleeper LA, Orav EJ, et al. (2006) Incidence, causes, and outcomes of dilated cardiomyopathy in children. Jama 296: 1867-1876. [Crossref]

17. Mason JW, O'connell JB, Herskowitz A, Rose NR, McManus BM, et al. (1995) A clinical trial of immunosuppressive therapy for myocarditis. N Engl J Med 333: 269275. [Crossref]

18. Kuhl U, Pauschinger M, Noutsias M, Seeberg B, Bock T, et al. (2005) High prevalence of viral genomes and multiple viral infections in the myocardium of adults with "idiopathic" left ventricular dysfunction. Circulation 111: 887-893. [Crossref]

19. Krejci J, Poloczková H, Hude P, Freiberger T, Němcová E, et al. (2013) Impact of inflammatory infiltration and viral genome presence in myocardium on the changes of echocardiographic parameters. Cor et vasa 55: e333-e340.

20. Kuhl U (2005) Antiviral treatment of myocarditis and acute dilated cardiomyopathy Heart Fail Clin 1: 467-474. [Crossref]

21. Kuhl U, Lassner D, von Schlippenbach J, Poller W, Schultheiss HP (2012) InterferonBeta improves survival in enterovirus-associated cardiomyopathy. $\mathrm{J} \mathrm{Am} \mathrm{Coll} \mathrm{Cardiol}$ 60: 1295-1296. [Crossref]

22. Calabrese F, Thiene G (2003) Myocarditis and inflammatory cardiomyopathy: microbiological and molecular biological aspects. Cardiovasc Res 60: 11-25. [Crossref]

23. Blauwet LA, Cooper LT (2010) Myocarditis. Prog Cardiovasc Dis 52: 274-288. [Crossref]

24. Bracamonte-Baran W, Ciháková D (2017) Cardiac autoimmunity: myocarditis. $A d v$ Exp Med Biol 1003: 187-221. [Crossref]

25. Cooper Jr LT (2009) Myocarditis. N Engl J Med 360: 1526-1538. [Crossref]

26. Kindermann I, Kindermann M, Kandolf R, Klingel K, Bultmann B, et al. (2008) Predictors of outcome in patients with suspected myocarditis. Circulation 118: 639648. [Crossref]

27. Martin AB, Webber S, Fricker FJ, Jaffe R, Demmler G, et al. (1994) Acute myocarditis. Rapid diagnosis by PCR in children. Circulation 90: 330-339. [Crossref]

28. Calabrese F, Rigo E, Milanesi O, Boffa GM, Angelini A, et al. (2002) Molecular diagnosis of myocarditis and dilated cardiomyopathy in children: clinicopathologic features and prognostic implications. Diagn Mol Pathol 11: 212-221. [Crossref]

29. Liu PP, Mason JW (2001) Advances in the understanding of myocarditis. Circulation 104: 1076-1082. [Crossref]

30. Gerzen P, Granath A, Holmgren B, Zetterquist S (1972) Acute myocarditis. A follow-up study. Br Heart $J 34: 575-583$. [Crossref]

31. Woodruff JF (1980) Viral myocarditis: a review. Am J Pathol 101: 425-484. [Crossref]

32. Grist NR, Reid D (1993) Epidemiology of viral infections of the heart. In: Banatvala JE, editor, Viral infections of the heart, London: Hodder and Stoughton, pp. 23-31.

33. Kasper EK, Agema WR, Hutchins GM, Deckers JW, Hare JM, et al. (1994) The causes of dilated cardiomyopathy: a clinicopathologic review of 673 consecutive patients. $J$ Am Coll Cardiol 23: 586-590. [Crossref]

34. Cambridge G, MacArthur CG, Waterson AP, Goodwin JF, Oakley CM (1979) Antibodies to Coxsackie B viruses in congestive cardiomyopathy. Br Heart J 41: 692696. [Crossref]

35. Muir P, Nicholson F, Tilzey AJ, Signy M, English TA, et al. (1989) Chronic relapsing pericarditis and dilated cardiomyopathy: serological evidence of persistent enterovirus infection. Lancet 1: 804-807. [Crossref]

36. Keeling PJ, Lukaszyk A, Poloniecki J, Caforio AL, Davies MJ, et al. (1994) A prospective case control study of antibodies to coxsackie B virus in idiopathic dilated cardiomyopathy. J Am Coll Cardiol 23: 593-598. [Crossref]

37. Karjalainen J, Nieminen MS, Heikkila J (1980) Influenza A1 myocarditis in conscripts. Acta Med Scand 207: 27-30. [Crossref]

38. Why HJ, Meany BT, Richardson PJ, Olsen EG, Bowles NE, et al. (1994) Clinical and prognostic significance of detection of enteroviral RNA in the myocardium of patients with myocarditis or dilated cardiomyopathy. Circulation 89: 2582-2589. [Crossref]

39. Fujioka S, Kitaura Y, Ukimura A, Deguchi H, Kawamura K, et al. (2000) Evaluation of viral infection in the myocardium of patients with idiopathic dilated cardiomyopathy. $J$ Am Coll Cardiol 36: 1920-1926. [Crossref]

40. Heber MM, Yu C, Towbin JA, Rogers BB (1995) Fatal Epstein-Barr virus myocarditis in a child with repetitive myocarditis. Pediatr Pathol Lab Med 15: 805-812. [Crossref]
41. Pauschinger M, Bowles NE, Fuentes-Garcia FJ, Pham V, Kühl U, et al. (1999) Detection of adenoviral genome in the myocardium of adult patients with idiopathic left ventricular dysfunction. Circulation 99: 1348-1354. [Crossref]

42. Spencer MJ, Cherry JD, Adams FH, Byatt PH (1975) Supraventricular tachycardia in an infant associated with a rhinoviral infection (letter). J Pediatr 86: 811-812. [Crossref]

43. Wreghitt T, Cary N (1993) Virus infections in heart transplant recipients and evidence for involvement of the heart. In: Banatvala JE, [Eds.], Viral infections of the heart, London: Hodder and Stoughton, pp. 240-250.

44. Maisch BE, Schönian U, Crombach MA, Wendl IN, Bethge C, et al. (1993) Cytomegalovirus associated inflammatory heart muscle disease. Scand J Infect Dis 88: 135-148. [Crossref]

45. Bandrup U, Morlensen SA (1984) Histopathological aspects of myocarditis with special reference to mumps, cytomegalovirus infection and the role of endomyocardial biopsy. In: Bolte HD, editor, Viral heart disease, Berlin: Springer, pp. 13-25.

46. Ni J, Bowles NE, Kim YH, Demmler G, Kearney D, et al. (1997) Viral infection of the myocardium in endocardial fibroelastosis. Molecular evidence for the role of mumps virus as an etiologic agent. Circulation 95: 133-139. [Crossref]

47. Porter HJ, Quantrill AM, Fleming KA (1988) B19 parvovirus infection of myocardia cells. Lancet 1: 535-536. [Crossref]

48. Schowengerdt KO, Ni J, Denfield SW, Gajarski RJ, Bowles NE, et al. (1997) Association of parvovirus B19 genome in children with myocarditis and cardiac allograft rejection diagnosis using the polymerase chain reaction. Circulation 96: 3549-3554. [Crossref]

49. Murry CE, Jerome KR, Reichenbach DD (2001) Fatal parvovirus myocarditis in a 5-year-old girl. Hum Pathol 32: 342-345. [Crossref]

50. Hall CJ (1994) Parvovirus B19 infection in pregnancy. Arch Dis Child Fetal Neonatal Ed 71: F4-F5. [Crossref]

51. Young NS (1996) Parvovirus. In: Fields BN, Knipe DM, Howley PM, editors, Virology, Philadelphia: Lippincot-Raven, pp. 2199-2220.

52. Matsumori A, Matoba Y, Sasayama S (1995) Dilated cardiomyopathy associated with hepatitis C virus infection. Circulation 92: 2519-2525. [Crossref]

53. Frustaci A, Calabrese F, Chimenti C, Pieroni M, Thiene G, Maseri A (2002) Lone hepatitis $\mathrm{C}$ virus myocarditis responsive to immunosuppressive therapy. Chest 122 : 1348-1356. [Crossref]

54. Anderson DW, Virmani R, Reilly JM, O'Leary T, Cunnion RE, et al. (1988) Prevalent myocarditis at necropsy in the acquired immunodeficiency syndrome. $\mathrm{J} \mathrm{Am} \mathrm{Coll}$ Cardiol 11: 792-799. [Crossref]

55. Hofman P, Drici MD, Gibelin P, Michiels JF, Thyss A (1993) Prevalence of toxoplasma myocarditis in patients with the acquired immunodeficiency syndrome. $\mathrm{Br}$ Heart $\mathrm{J} 70$ 376-381. [Crossref]

56. Breinholt JP, Moulik M, Dreyer WJ, Denfield SW, Kim JJ, et al. (2010) Viral epidemiologic shift in inflammatory heart disease: the increasing involvement of parvovirus B19 in the myocardium of pediatric cardiac transplant patients. J Heart Lung Transplant 29: 739-746. [Crossref]

57. Maisch B, Pankuweit S (2012) Current treatment options in (peri) myocarditis and inflammatory cardiomyopathy. Herz 37: 644-656. [Crossref]

58. Bowles NE, Ni J, Kearney DL, Pauschinger M, Schultheiss HP (2003) Detection of viruses in myocardial tissues by polymerase chain reaction. evidence of adenovirus as a common cause of myocarditis in children and adults. $J$ Am Coll Cardiol 42: 466-472. [Crossref]

59. Havaldar PV (1992) Diphtheria in the eighties: experience in a south Indian district hospital. J Indian Med Assoc 90: 155-156. [Crossref]

60. Bjorkholm B, Olling S, Larsson P, Hagberg L (1987) An outbreak of diphtheria among Swedish alcoholics. Infection 15: 354-358. [Crossref]

61. Putterman C, Caraco Y, Shalit M (1991) Acute non-rheumatic perimyocarditis complicating streptococcal tonsillitis. Cardiology 78: 156-160. [Crossref]

62. Li Y, Pan Z, Ji Y, Peng T, Archard LC, et al. (2000) Enterovirus replication in valvular tissue from patients with chronic rheumatic heart disease. Eur Heart $J$ 23: 567-573. [Crossref]

63. Hardman JM, Earle KM (1969) Myocarditis in 200 fatal meningococcal infections. Arch Pathol 87: 318-325. [Crossref]

64. Zollner B, Sobottka I, von der Lippe G (1992) Perimyocarditis caused by Yersinia enterocolitica serotype 0:3. Dtsch Med Wochenschr 117: 1794-1797. [Crossref] 
65. Van der Linde MR, Crijns HJ, de Koning (1990) Range of atrioventricular conduction disturbances in Lyme borreliosis: a report of four cases and review of other published reports. Br Heart J 63: 162-168. [Crossref]

66. Karjalainen J (1990) A loud third heart sound and asymptomatic myocarditis during Mycoplasma pneumoniae infection. Eur Heart J 11: 960-963. [Crossref]

67. Odeh M, Oliven A (1992) Chlamydial infections of the heart. Eur J Clin Microbiol Infect Dis 11: 885-893. [Crossref]

68. Page SR, Stewart JT, Bernstein JJ (1988) A progressive pericardial effusion caused by psittacosis. Br Heart J 60: 87-89. [Crossref]

69. Wesslen L, Pahlson C, Friman G, Fohlman J, Lindquist O, et al. (1992) Myocarditis caused by Chlamydia pneumoniae (TWAR) and sudden unexpected death in a Swedish elite orienteer. Lancet 340: 427-428. [Crossref]

70. Fournier PE, Etienne J, Harle JR, Habib G, Raoult D (2001) Myocarditis, a rare but severe manifestation of $\mathrm{Q}$ fever: report of eight cases and review of the literature. Clin Infect Dis 32: 1440-1447. [Crossref]

71. Parada H, Carrasco HA, Anez N, Fuenmayor C, Inglessis I (1997) Cardiac involvement is a constant finding in acute Chagas' disease: a clinical, parasitological and histopathological study. Int J Cardiol 60: 49-54. [Crossref]

72. Tsala Mbala P, Blackett K, Mbonifor CL, Leke R, Etoundi J (1988) Functional and immunologic involvement in human African trypanosomiasis caused by Trypanosoma gambiense. Bull Soc Pathol Exot Filiales 81: 490-501. [Crossref]

73. Wreghitt TG, Hakim M, Gray JJ (1989) Toxoplasmosis in heart and heart and lung transplant recipients. J Clin Pathol 42: 194-199. [Crossref]

74. Wreghitt T, Cary N (1993) Virus infections in heart transplant recipients and evidence for involvement of the heart. In: Banatvala JE, editor, viral infections of the heart, London: Hodder and Stoughton, pp. 240-250.

75. Nosanchuk JD (2002) Fungal myocarditis. Front Biosci 7: 1423-1438. [Crossref]

76. Calabrese F, Angelini A, Cecchetto A, Valente M, Livi U, et al. (1998) HIV infection in the first heart transplantation in Italy: fatal outcome. Case report. APMIS 106: 470474. [Crossref]

77. Maizels RM, Balic A, Gomez-Escobar N, Nair M, Taylor MD, et al. (2004) Helminth parasites-masters of regulation. Immunol Rev 201: 89-116. [Crossref]

78. Bethony J, Brooker S, Albonico M, Geiger SM, Loukas A, et al. (2006) Soil-transmitted helminth infections: ascariasis, trichuriasis, and hookworm. Lancet 367: 1521-1532. [Crossref]

79. Bauer BS, Li A, Bradfield JS (2018) Arrhythmogenic inflammatory cardiomyopathy: A review. Arrhythm Electrophysiol Rev 7: 181-186. [Crossref]

80. Mackay IR, Leskovsek NV, Rose NR (2008) Cell damage and autoimmunity: a critical appraisal. J Autoimmun 30: 5-11. [Crossref]

81. Bracamonte-Baran W, Burlingham W (2015) Non-inherited maternal antigens, pregnancy, and allotolerance. Biom J 38: 39-51. [Crossref]

82. Von Herrath MG, Oldostone MBA (1996) Virus-induced autoimmune disease. Curr Opin Immunol 8: 878-885. [Crossref]

83. Mountz JD, Talal N (1993) Retrovirus, apoptosis and autogenes. Immunol Today 14: 532-536. [Crossref]

84. Yoshida S, Gershwin E (1993) Autoimmunity and selected environmental factors of disease induction. Semin Arthritis Rheum 22: 399-419. [Crossref]

85. Griem P, Gleichmann E (1995) Metal ion induced autoimmunity. Curr Opin Immuno 7: 831-838. [Crossref]

86. Lanzavecchia A (1995) How can crytic epitopes trigger autoimmunity? J Exp Med 181: 1945-1948. [Crossref]

87. San Martín MA, García Á, Rodríguez FJ, Terol I (2002) Dilated cardiomyopathy and autoimmunity: an overview of current knowledge and perspectives. Rev Esp Cardiol 55: 514-524. [Crossref]

88. Fu M, Matsui S (2005) Is cardiomyopathy an autoimmune disease? Keio J Med 51: 208-212. [Crossref]

89. Neumann DA (1994) Autoimmunity and idiopathic dilated cardiomyopathy. Mayo Clin Proc 69: 193-195. [Crossref]

90. Yoshikawa T, Baba A, Nagatomo Y (2009) Autoimmune mechanisms underlying dilated cardiomyopathy. Circ J 73: 602-607[Crossref]
91. Caforio AL, Bottaro S, Iliceto S (2012) Dilated cardiomyopathy (DCM) and myocarditis: classification, clinical and autoimmune features. Appl Cardiopulm Pathophysiol 16: 82-95.

92. Chaigne B, Scirè CA, Talarico R, Alexander T, Amoura Z, et al. (2019) Mixed connective tissue disease: state of the art on clinical practice guidelines. RMD Open 4: e000783. [Crossref]

93. Zawadowski GM, Klarich KW, Moder KG, Edwards WD, Cooper LT Jr. (2012) A contemporary case series of lupus myocarditis. Lupus 21: 1 378-1384. [Crossref]

94. Wu AH (2008) Cardiotoxic drugs: clinical monitoring and decision-making. Heart 94: 1503-1509. [Crossref]

95. Figueredo VM (2011) Chemical cardiomyopathies: the negative effects of medications and non-prescribed drugs on the heart. Am J Med 124: 480-488. [Crossref]

96. Lipshultz SE, Lipsitz SR, Mone SM, Goorin AM, Sallan SE, et al. (1995) Female sex and drug dose as risk factors for late cardiotoxic effects of dox-Female sex and drug dose as risk factors for late cardiotoxic effects of doxorubicin therapy for childhood cancer. $N$ Engl J Med 332: 1738-1743. [Crossref]

97. Steinherz LJ, Steinherz PG, Tan CT, Heller G, Murphy ML (1991) Cardiac toxicity 4 to 20 years after completing anthracycline therapy. Jama 266: 1672-1677. [Crossref]

98. Zucchi R, Danesi R (2003) Cardiac toxicity of antineoplastic anthracyclines. Curr Med Chem Anticancer Agents 3: 151-171. [Crossref]

99. Takemura G, Fujiwara H (2007) Doxorubicin-induced cardiomyopathy: from the cardiotoxic mechanisms to management. Prog Cardiovasc Dis 49: 330-352. [Crossref]

100. Jones LW, Haykowsky MJ, Swartz JJ, Douglas PS, Mackey JR (2007) Early breast cancer therapy and cardiovascular injury. $J$ Am Coll Cardiol 50: 1435-1441. [Crossref]

101. Lipshultz SE, Alvarez JA, Scully RE (2008) Anthracycline associated cardiotoxicity in survivors of childhood cancer. Heart 94: 525-533. [Crossref]

102. Steinherz LJ, Brochstein JA, Robins J. 1986. Cardiac involvement in congenita acquired immunodeficiency syndrome. Am J Dis Child 140: 1241-1244. [Crossref]

103. Joshi VV, Gadol C, Connor E, Oleske JM, Mendelson J, et al. (1988) Dilated cardiomyopathy in children with acquired immunodeficiency syndrome: A pathologic study of five cases. Hum Pathol 19: 69-73. [Crossref]

104. Johann-Liang R, Cervia JS, Noel GJ (1997) Characteristics of human immunodeficiency virus-infected children at the time of death: an experience in the 1990s. Pediatr Infect Dis J 16: 1145-1150. [Crossref]

105. Brady MT, Oleske JM, Williams PL, Elgie C, Mofenson LM, et al. (2010) Pediatric AIDS Clinical Trials Group219/219C Team. Declines in mortality rates and changes in causes of death in HIV-1-infected children during the HAART era. $J$ Acquir Immune Defic Syndr 53: 86-94. [Crossref]

106. Barbarini G, Barbaro G (2003) Incidence of the involvement of the cardiovascular system in HIV infection. Aids 17: S46-S50. [Crossref]

107. Jain N, Reddy DH, Verma SP, Khanna R, Vaish AK, et al. (2014) Cardiac abnormalities in HIV-positive patients: results from an observational study in India. $J$ Int Assoc Provid AIDS Care 13: 40-46. [Crossref]

108. Friis-Møller N, Sabin CA, Weber R, d'Arminio MA, El-Sadr WM, et al. (2003) Combination antiretroviral therapy and the risk of myocardial infarction. $N$ Engl $J$ Med 349: 1993-2003. [Crossref]

109. D'Arminio A, Sabin CA, Phillips AN, Reiss P, Weber R, Kirk O, et al. (2004) Cardioand cerebrovascular events in HIV-infected persons. Aids 18: 1811-1817. [Crossref]

110. Lewis W, Haase CP, Raidel SM, Russ RB, Sutliff RL, et al. (2001) Combined antiretroviral therapy causes cardiomyopathy and elevates plasma lactate in transgenic AIDS mice. Laboratory Investigation 81: 1527-1536. [Crossref]

111. Chaisson RE, Allain JP, Leuther M, Volberding PA (1986) Significant changes in HIV antigen level in the serum of patients treated with azidothymidine. $N$ Engl J Med 315 : 1610-1611. [Crossref]

112. Yogasundaram H, Hung W, Paterson ID, Sergi C, Oudit GY (2018) Chloroquineinduced cardiomyopathy: a reversible cause of heart failure. ESC Heart Fail 5: 372 375. [Crossref]

113. August C, Holzhausen HJ, Schmoldt A, Pompecki R, Schroder S (1995) Histological and ultrastructural findings in chloroquine-induced cardiomyopathy. J Mol Med 73: 73-77. [Crossref]

114. Volkov VP (2018) Antipsychotic cardiomyopathy: to the problem of clinical diagnosis. MOJ Toxicol 4: 238-240. 
115. Schwartz J, Sartini D, Huber S (2004) Myocarditis susceptibility in female mice depends upon ovarian cycle phase at infection. Virology 330: 16-23. [Crossref]

116. Badorff C, Lee GH, Lamphear BJ, Martone ME, Campbell KP, et al. (1999) Enteroviral protease $2 \mathrm{~A}$ cleaves dystrophin: evidence of cytoskeletal disruption in an acquired cardiomyopathy. Nat Med 5: 320-326. [Crossref]

117. Lozano MD, Rubocki RJ, Wilson JE, McManus BM, Wisecarver JL, et al. (1997) Human leukocyte antigen class II associations in patients with idiopathic dilated cardiomyopathy. Myocarditis Treatment Trial Investigators. J Card Fail 3: 97-103. [Crossref]

118. Tchilian EZ, Gil J, Navarro ML (2006) Unusual case presentations associated with the CD45C77G polymorphism. Clin Exp Immunol 146: 448-454. [Crossref]

119. Beck MA, Levander OA, Handy J (2003) Selenium deficiency and viral infection. $J$ Nutr 133: 1463S-1467S. [Crossref]

120. Ilback NG, Wesslen L, Fohlman J (1996) Effects of methyl mercury on cytokines, inflammation and virus clearance in a common infection (coxsackie B3 myocarditis). Toxicol Lett 89: 19-28. [Crossref]

121. Cooper LT, Rader V, Ralston NV (2007) The roles of selenium and mercury in the pathogenesis of viral cardiomyopathy. Congest Heart Fail (Greenwich, Conn) 13: 193-199. [Crossref]

122. Tracy S, Hofling K, Pirruccello S (2000) Group B coxsackievirus myocarditis and pancreatitis: connection between viral virulence phenotypes in mice. Journal of medical virology 62: 70-81. [Crossref]

123. Bergelson JM, Cunningham JA, Droguett G (1997) Isolation of a common receptor for Coxsackie B viruses and adenoviruses 2 and 5. Science 275: 1320-1323. [Crossref]

124. Salone B, Martina Y, Piersanti S (2003) Integrin alpha3betal is an alternative cellular receptor for adenovirus serotype 5. J Virol 77: 13448-13454. [Crossref]

125. Shafren DR, Bates RC, Agrez MV (1995) Coxsackieviruses B1, B3, and B5 use decay accelerating factor as a receptor for cell attachment. J Virol 69: 3873-3877. [Crossref]

126. Wickham TJ, Filardo EJ, Cheresh DA (1994) Integrin alpha v beta 5 selectively promotes adenovirus mediated cell membrane permeabilization. J Cell Biol 127 257-264. [Crossref]

127. Wickham TJ, Mathias P, Cheresh DA (1993) Integrins alpha v beta 3 and alpha beta 5 promote adenovirus internalization but not virus attachment. Cell 73: 309-319. [Crossref]

128. Fechner H, Noutsias M, Tschoepe (2003) Induction of coxsackievirus-adenovirusreceptor expression during myocardial tissue formation and remodeling: identification of a cell-to-cell contact-dependent regulatory mechanism. Circulation 107: 876-882. [Crossref]

129. Kashimura T, Kodama M, Hotta Y (2004) Spatiotemporal changes of coxsackievirus and adenovirus receptor in rat hearts during postnatal development and in cultured cardiomyocytes of neonatal rat. Virchows Arch 444: 283-292. [Crossref]

130. Shi Y, Chen C, Lisewski U (2009) Cardiac deletion of the Coxsackievirus-adenovirus receptor abolishes Coxsackievirus B3 infection and prevents myocarditis in vivo. $J$ Am Coll Cardiol 53: 1219-1226. [Crossref]

131. Huber SA (2006) Autoimmunity in coxsackievirus B3 induced myocarditis. Autoimmunity 39: 55-61. [Crossref]

132. Huang CH, Vallejo JG, Kollias G (2009) Role of the innate immune system in acute viral myocarditis. Basic Res Cardiol 104: 228-237. [Crossref]

133. Lowenstein CJ, Hill SL, Lafond-Walker A. 1996. Nitric oxide inhibits viral replication in murine myocarditis. J Clin Invest 97: 1837-1843. [Crossref]

134. Szalay G, Sauter M, Hald J, Weinzierl A, Kandolf R, et al. (2006) Sustained nitric oxide synthesis contributes to immunopathology in ongoing myocarditis attributable to interleukin-10 disorders. Am J Pathol 169: 2085-2093. [Crossref]

135. Hardarson HS, Baker JS, Yang Z (2007) Toll-like receptor 3 is an essential component of the innate stress response in virus-induced cardiac injury. Am J Physiol 292: H251-H258. [Crossref]

136. Fuse K, Liu Y, Chen MY, Yeh WC, Liu P (2005) Myeloid differentiation factor- 88 plays a crucial role in the pathogenesis of Coxsackievirus B3-induced myocarditis and influences type I interferon production. Circulation 112: 2276-2285. [Crossref]

137. Fairweather D, Frisancho-Kiss S, Njoku DB, Nyland JF, Kaya Z, et al. (2006) Complement receptor 1 and 2 deficiency increases coxsackievirus B3-induced myocarditis, dilated cardiomyopathy, and heart failure by increasing macrophages, IL-1beta, and immune complex deposition in the heart. J Immunol 176: 3516-3524. [Crossref]
138. Chow LH, Beisel KW, McManus BM (1992) Enteroviral infection of mice with severe combined immunodeficiency. Evidence for direct viral pathogenesis of myocardial injury. Lab Invest 66: 24-31. [Crossref]

139. Lamphear BJ, Yan RI, Yang F, Waters D, Liebig HD, et al. (1993) Mapping the cleavage site in protein synthesis initiation factor eIF-4 gamma of the $2 \mathrm{~A}$ proteases from human Coxsackievirus and rhinovirus. J Biol Chem 268: 19200-19203. [Crossref]

140. Xiong D, Yajima T, Lim BK, et al. (2007) Inducible cardiac-restricted expression of enteroviral protease $2 \mathrm{~A}$ is sufficient to induce dilated cardiomyopathy. Circulation 115: 94-102. [Crossref]

141. Chau DH, Yuan J, Zhang H, Cheung P, Lim T (2007) Coxsackievirus B3 proteases $2 \mathrm{~A}$ and $3 \mathrm{C}$ induce apoptotic cell death through mitochondrial injury and cleavage of eIF4GI but not DAP5/p97/NAT1. Apoptosis 12: 513-524. [Crossref]

142. Pummerer C, Berger P, Frühwirth M, Ofner C, Neu N, et al. (1991) Cellular infiltrate, major histocompatibility antigen expression and immunopathogenic mechanisms in cardiac myosin-induced myocarditis. Lab Invest 65: 538-547. [Crossref]

143. Göser S, Öttl R, Brodner A, Dengler TJ, Torzewski J, et al. (2005) Critical role for monocyte chemoattractant protein-1 and macrophage inflammatory protein-1alpha in induction of experimental autoimmune myocarditis and effective anti-monocyte chemoattractant protein-1 gene therapy. Circulation 112: 3400-3407. [Crossref]

144. Rangachari M, Mauermann N, Marty RR, Dirnhofer S, Kurrer MO, et al. (2006) T-bet negatively regulates autoimmune myocarditis by suppressing local production of interleukin 17. J Exp Med 203: 2009-2019. [Crossref]

145. Haga T, Suzuki JI, Kosuge H, Ogawa M, Saiki H, et al. (2009) Attenuation of experimental autoimmune myocarditis by blocking T cell activation through 4-1BB pathway. J Mol Cell Cardiol 46: 719-727. [Crossref]

146. Afanasyeva M, Wang Y, Kaya Z, Park S, Zilliox MJ, et al. (2001) Experimenta autoimmune myocarditis in A/J mice is an interleukin-4-dependent disease with a Th2 phenotype. Autoimmunity 159: 193-203. [Crossref]

147. Eriksson U, Ricci R, Hunziker L, Kurrer MO, Oudit GY, et al. (2003) Dendritic cellinduced autoimmune heart failure requires cooperation between adaptive and innate immunity. Nat Med 9: 1484-1490. [Crossref]

148. Hayward SL, Bautista-Lopez N, Suzuki K, Atrazhev A, Dickie P, et al. (2006) CD4 T cells play major effector role and CD8 T cells initiating role in spontaneous autoimmune myocarditis of HLA-DQ8 transgenic IAb knockout nonobese diabetic mice. J Immunol 176: 7715-7725. [Crossref]

149. Neumann DA, Rose NR, Ansari AA, Herskowitz A (1994) Induction of multiple heart autoantibodies in mice with coxsackievirus B3- and cardiac myosin-induced autoimmune myocarditis. J Immunol 152: 343-350. [Crossref]

150. Caforio AL, Mahon NJ, Tona F, McKenna WJ (2002) Circulating cardiac autoantibodies in dilated cardiomyopathy and myocarditis: pathogenetic and clinical significance. Eur J Heart Fail 4: 411-417. [Crossref]

151. Neumann DA, Burek CL, Baughman KL, Rose NR, Herskowitz A (1990) Circulating heart-reactive antibodies in patients with myocarditis or cardiomyopathy. $J \mathrm{Am} \mathrm{Coll}$ Cardiol 16: 839-846. [Crossref]

152. Caforio AL, Mahon NJ, McKenna WJ (2001) Cardiac autoantibodies to myosin and other heart-specific autoantigens in myocarditis and dilated cardiomyopathy. Autoimmunity 34: 199-204. [Crossref]

153. Wallukat G, Morwinski M, Kowal K, Förster A, Boewer V, et al. (1991) Autoantibodies against the beta-adrenergic receptor in human myocarditis and dilated cardiomyopathy: beta-adrenergic agonism without desensitization. Eur Heart $J$ 12: 178-181. [Crossref]

154. Staudt A, Dorr M, Staudt Y, et al. (2005) Role of immunoglobulin G3 subclass in dilated cardiomyopathy: results from protein A immunoadsorption. Am Heart J 150: 729-736. [Crossref]

155. Warraich RS, Noutsias M, Kasac I, Seeberg B, Dunn MJ, et al. (2002) Immunoglobulin G3 cardiac myosin autoantibodies correlate with left ventricular dysfunction in patients with dilated cardiomyopathy: immunoglobulin G3 and clinical correlates. Am Heart J 143: 1076-1084. [Crossref]

156. Latva-Hirvelä J, Kytö V, Saraste A, Eriksson S, Vuorinen T, et al. (2009) Development of troponin autoantibodies in experimental coxsackievirus B3 myocarditis. Eur J Clin Invest 39: 457-462. [Crossref]

157. Kaya Z, Katus HA, Rose NR (2009) Cardiac troponins and autoimmunity: Their role in the pathogenesis of myocarditis and of heart failure. Clin Immunol 134: 80-88. [Crossref] 
158. Goser S, Andrassy M, Buss SJ, Leuschner F, Volzet CH, et al. (2006) Cardiac troponin I but not cardiac troponin $\mathrm{T}$ induces severe autoimmune inflammation in the myocardium. Circulation 114: 1693-1702. [Crossref]

159. Gewirtz D (1999) A critical evaluation of the mechanisms of action proposed for the antitumor effects of the anthracycline antibiotics adriamycin and daunorubicin. Biochem Pharmacol 57: 727-741. [Crossref]

160. Horenstein MS, Vander Heide RS, L'Ecuyer TJ (2000) Molecular basis of anthracycline-induced cardiotoxicity and its prevention. Mol Genet Metab 71: 436444. [Crossref]

161. Hershko C, Link G, Tzahor M, Pinson A (1993) The role of iron and iron chelators in anthracycline cardiotoxicity. Leuk Lymphoma 11: 207-214. [Crossref]

162. Link G, Tiros R, Pinson A, Hershko C (1996) Role of iron in the potentiation of anthracycline cardiotoxicity: identification of heart cell mitochondria as a major site of iron-anthracycline interaction. J Lab Clin Med 127: 272-278. [Crossref]

163. Doroshow JH, Locker GY, Myers CE (1980) Enzymatic defenses of the mouse hear against reactive oxygen metabolites: alterations produced by doxorubicin. $J$ Clin Invest 65: 128-135. [Crossref]

164. Shakir DK, Rasul KI (2009) Chemotherapy induced cardiomyopathy: pathogenesis, monitoring and management. J Clin Med Res 1: 8-12. [Crossref]

165. Doroshow JH (1983) Effect of anthracycline antibiotics on oxygen radical formation in rat heart. Cancer Res 43: 460-472. [Crossref]

166. Ehrke MJ, Maccubbin D, Ryoyama K, Cohen SA, Mihich E (1986) Correlation between adriamycin-induced augmentation of interleukin 2 production and of cellmediated cytotoxicity in mice. Cancer Res 46: 54-60. [Crossref]

167. Zhang S, Liu X, Bawa-Khalfe T, Lu LS, Lyu YL, et al. (2012) Identification of the molecular basis of doxorubicin-induced cardiotoxicity. Nat Med 18: 1639-1642. [Crossref]

168. Wouters KA, Kremer L, Miller TL, Herman EH, Lipshultz SE (2005) Protecting against anthracycline-induced myocardial damage: a review of the most promising strategies. Br J Haematol 131: 561-578. [Crossref]

169. Kalyanaraman BJ, Joseph J, Kalivendi S, Wang S, Konorev E, et al. (2002) Doxorubicin-induced apoptosis: implications in cardiotoxicity. In Oxygen/Nitrogen Radicals: Cell Injury and Disease. pp. 119-124.

170. Caforio AL., Marcolong R, Basso C, Iliceto S (2015) Clinical presentation and diagnosis of myocarditis. Heart 101: 1332-1344. [Crossref]

171. Schultheiss HP, Kuhl U, Cooper LT (2011) The management of myocarditis. Eur Heart L 32: 2616-2625. [Crossref]

172. D'ambrosio A, Patti G, Manzoli A, Sinagra G, Di Lenarda A, et al. (2001) The fate of acute myocarditis between spontaneous improvement and evolution to dilated cardiomyopathy: a review. Heart 85: 499-504. [Crossref]

173. Mason JW, O'connell JB, Herskowitz A, Rose NR, McManus BM, et al. (1995) A clinical trial of immunosuppressive therapy for myocarditis. N Engl J Med 333: 269275. [Crossref]

174. Kania G, Blyszczuk P, Müller-Edenborn B, Eriksson U (2013) Novel therapeutic options in inflammatory cardiomyopathy. Swiss Medical Weekly 143: 13841. [Crossref]

175. Krejci J, Hude P, Poloczkova H, Zampachova V, Stepanova R, et al. (2016) Correlations of the changes in bioptic findings with echocardiographic, clinical and laboratory parameters in patients with inflammatory cardiomyopathy. Heart Vessels 31: 416-426. [Crossref]

176. Tschope C, Bock CT, Kasner M, Noutsias M, Westermann D, et al. (2005) High prevalence of cardiac parvovirus B19 infection in patients with isolated left ventricular diastolic dysfunction. Circulation 111: 879-886. [Crossref]

177. Baccouche H, Mahrholdt H, Meinhardt G, Merher R, Voehringer M, et al. (2009) Diagnostic synergy of non-invasive cardiovascular magnetic resonance and invasive endomyocardial biopsy in troponin-positive patients without coronary artery disease. Eur Heart J 30: 2869-2879. [Crossref]

178. Ukena C, Mahfoud F, Kindermann I, Kandolf R, Kindermann M, et al. (2011) Prognostic electrocardiographic parameters in patients with suspected myocarditis. Eur J Heart Fail 13: 398-405. [Crossref]

179. Friedrich MG, Sechtem U, Schulz-Menger J, Holmvang G, Alakija P, et al. (2009) International Consensus Group on Cardiovascular magnetic resonance in myocarditis: A JACC White Paper. J Am Coll Cardiol 53: 1475-1487. [Crossref]
180. Friedrich MG (2008) Tissue characterization of acute myocardial infarction and myocarditis by cardiac magnetic resonance. JACC Cardiovasc Imaging 1: 652-662. [Crossref]

181. Ferreira VM, Piechnik SK, Dall'Armellina E, Karamitsos TD, Francis JM, et al (2013) T mapping for the diagnosis of acute myocarditis using CMR: comparison to T2-weighted and late gadolinium enhanced imaging. JACC Cardiovasc Imaging 6 : 1048-1058. [Crossref]

182. Monney PA, Sekhri N, Burchell T, Knight C, Davies C., et al. (2011) Acute myocarditis presenting as acute coronary syndrome: role of early cardiac magnetic resonance in its diagnosis. Heart 97: 1312-1318. [Crossref]

183. Yancy CW, Jessup M, Bozkurt B, Butler J, Casey DE, et al. (2013) ACCF/AHA guideline for the management of heart failure: a report of the American College of Cardiology Foundation/American Heart Association Task Force on Practice Guidelines. J Am Coll Cardiol 62: e147-e239. [Crossref]

184. Cooper LT, Baughman KL, Feldman AM, Frustaci A, Jessup M, et al. (2007) The role of endomyocardial biopsy in the management of cardiovascular disease: a scientific statement from the American Heart Association, the American College of Cardiology, and the European Society of Cardiology. Eur Heart J 28: 3076-3093. [Crossref]

185. McMurray JJ, Adamopoulos S, Anker SD, Auricchio A, Böhm M, et al. (2012) ESC Guidelines for the diagnosis and treatment of acute and chronic heart failure 2012: The Task Force for the Diagnosis and Treatment of Acute and Chronic Heart Failure 2012 of the European Society of Cardiology. Developed in collaboration with the Heart Failure Association (HFA) of the ESC. Eur J Heart Fail 14: 803-869. [Crossref]

186. Kim JS, Judson MA, Donnino R, Gold M, Cooper LT Jr. (2009) Cardiac sarcoidosis Am Heart J 157: 9-21. [Crossref]

187. Ghio S, Gavazzi A, Campana C, Inserra C, Klersy C, et al. (2001) Independent and additive prog nostic value of right ventricular systolic function and pulmonary artery pressure in patients with chronic heart failure. J Am Coll Cardiol 37: 183-188. [Crossref]

188. Ren H, Poston RS Jr, Hruban RH, Baumgartner WA, Baughman KL, et al. (1993) Long survival with giant cell myocarditis. Mod Pathol 6: 402-407. [Crossref]

189. Das BB, Recto M, Johnsrude C, Klein L, Orman K, et al. (2006) Cardiac transplantation for paediatric giant cell myocarditis. J Heart Lung Transplant 25 474-478. [Crossref]

190. Winter MP, Sulzgruber P, Koller L, Bartko P, Goliasch G, et al. (2018) Immunomodulatory treatment for lymphocytic myocarditis: a systematic review and meta-analysis. Heart Fail Rev 23: 573-581. [Crossref]

191. Stanton C, Mookadam F, Cha S, McNamara D, Aukrust P, et al. (2008) Greater symptom duration predicts response to immunomodulatory therapy in dilated cardiomyopathy. Int J Cardiol 128: 38-41. [Crossref]

192. Moher D, Liberati A, Tetzlaff J, Altman DG, Prisma Group (2009) Preferred reporting items for systematic reviews and meta-analyses: the PRISMA statement. PLoS Medicine 6: e1000097. [Crossref]

193. Chan KY, Iwahara M, Benson LN, Wilson GJ, Freedom RM (1991) Immunosuppressive therapy in the management of acute myocarditis in children: a clinical trial. J Am Coll Cardiol 17: 458-460. [Crossref]

194. Escher F, Kühl U, Lassner D, Poller W, Westermann D, et al. (2016) Long-term outcome of patients with virus-negative chronic myocarditis or inflammatory cardiomyopathy after immunosuppressive therapy. Clin Res Cardiol 105: 1011-1120. [Crossref]

195. Frustaci A, Chimenti C, Calabrese F, Pieroni M, Thiene G, et al, (2003) Immunosuppressive therapy for active lymphocytic myocarditis: virological and immunologic profile of responders versus nonresponders. Circulation 107: 857-863. [Crossref]

196. Frustaci A, Russo MA, Chimenti C (2009) Randomized study on the efficacy of immunosuppressive therapy in patients with virus-negative inflammatory cardiomyopathy: the TIMIC study. Eur Heart J 30: 1995-2002. [Crossref]

197. Gullestad L, Aass H, Fjeld JG, Wikeby L, Andreassen AK, et al. (2001) Immunomodulating therapy with intravenous immunoglobulin in patients with chronic heart failure. Circulation 103: 220-225. [Crossref]

198. Kuhl U, Pauschinger M, Schwimmbeck PL, Seeberg B, Lober C, et al. (2003) Interferon- $\beta$ treatment eliminates cardiotropic viruses and improves left ventricula function in patients with myocardial persistence of viral genomes and left ventricular dysfunction. Circulation 107: 2793-2798. [Crossref] 
199. Mason JW, O'connell JB, Herskowitz A, Rose NR, McManus BM, et al. (1995) Myocarditis Treatment Trial Investigators. A clinical trial of immunosuppressive therapy for myocarditis. New Engl J Med 333: 269-275. [Crossref]

200. McNamara DM, Holubkov R, Starling RC, Dec GW, Loh E, et al. (2001) Controlled trial of intravenous immune globulin in recent-onset dilated cardiomyopathy. Circulation 103: 2254-2259. [Crossref]

201. Merken J, Hazebroek M, Van Paassen P, Verdonschot J, Van Empel V, et al. (2018) Immunosuppressive therapy improves both short-and long-term prognosis in patients with virus-negative nonfulminant inflammatory cardiomyopathy. Circulation Heart Fail 11: e004228. [Crossref]

202. Parrillo JE, Cunnion RE, Epstein SE, Parker MM, Suffredini AF, et al. (1989) A prospective, randomized, controlled trial of prednisone for dilated cardiomyopathy. New Engl J Med 321: 1061-1068. [Crossref]

203. Staudt A, Schaper F, Stangl V, Plagemann A, Bohm M, et al. (2001) Immunohistological changes in dilated cardiomyopathy induced by immunoadsorption therapy and subsequent immunoglobulin substitution. Circulation 103: 2681-2686. [Crossref]

204. Weinmann K, Werner J, Rottbauer W, Walcher D (2017) P2575Immunoadsorption therapy additional to standard medical treatment leads to significant improvement of left ventricular function in post-inflammatory cardiomyopathy. Eur Heart J Suppl 38: 1-1.
205. Weinmann K, Werne J, Koenig W, Rottbauer W, Walcher D, et al. (2019) Use of Cardiac Biomarkers for Monitoring Improvement of Left Ventricular Function by Immunoadsorption Treatment in Dilated Cardiomyopathy. Biomolecules 9: 654. [Crossref]

206. Wojnicz R, Nowalany-Kozielska E, Wojciechowska C, Glanowska G, Wilczewski P, et al. (2001) Randomized, placebo-controlled study for immunosuppressive treatment of inflammatory dilated cardiomyopathy: two-year follow-up results. Circulation 104: 39-45. [Crossref]

207. Hia CPP, Yip WCL, Tai BC, Quek SC (2004) Immunosuppressive therapy in acute myocarditis: an 18 year systematic review. Arch Dis Child 89: 580-584. [Crossref]

208. WinterMP, Sulzgruber P Koller L, Bartko P, Goliasch G, Niessner A (2018) Immunomodulatory treatment for lymphocytic myocarditis: A systematic review and meta-analysis. Heart Fail Rev 23: 573-581. [Crossref]

209. Maisch B, Herzum M, Hufnagel, Bethge C, Schönian U (1995) Immunosuppressive treatment for myocarditis and dilated cardiomyopathy. Eur Heart $J$ 16: 153-161. [Crossref]

Copyright: $(02020$ Albakri A. This is an open-access article distributed under the terms of the Creative Commons Attribution License, which permits unrestricted use, distribution, and reproduction in any medium, provided the original author and source are credited. 